\title{
Diagnóstico da degradação ambiental na Vertente Úmida do Maciço de Uruburetama/CE e seu entorno
}

\author{
Diagnosis of environmental degradation in the humid slope of the \\ Uruburetama Massif and its surroundings
}

\author{
Eduardo Viana Freires' ${ }^{(\mathbb{D})}$, Cláudio Ângelo da Silva Neto' ${ }^{(\mathbb{D}}$, Cynthia $^{\circ}$ \\ Romariz Duarte $^{1}{ }^{(\mathbb{D}}$, César Ulisses Vieira Veríssimo' $^{(\mathbb{D}}$, Daniel \\ Dantas Moreira Gomes" ${ }^{10}$, Allison de Oliveira Maia'(D) \\ ' Universidade Federal do Ceará, Fortaleza, CE, Brasil \\ "Universidade de Pernambuco, Garanhuns, PE, Brasil
}

\section{RESUMO}

As diversas intervenções no Maciço de Uruburetama têm gerado um quadro de degradação que compromete a sustentabilidade econômica, social e ambiental local. Como forma de alertar sobre o agravamento dos problemas ambientais, esta pesquisa objetiva realizar um diagnóstico da degradação ambiental na vertente úmida do Maciço de Uruburetama/CE e seu entorno, com intuito de avaliar os impactos gerados a partir das ações antrópicas. A metodologia da pesquisa consistiu na aquisição de dados, em que houve a revisão bibliográfica, a obtenção de imagens orbitais e dados vetoriais; e a realização de atividades de campo para reconhecimento e identificação do uso e ocupação da terra e dos impactos associados. Posteriormente esses dados e ações subsidiaram a caracterização e o mapeamento temático da área de pesquisa. A partir da integração desses dados foi verificado que a vertente úmida do Maciço de Uruburetama apresenta avançado estágio de degradação a partir da expansão urbana e das atividades agrícolas. As intervenções ocorrem inclusive nas áreas de preservação permanente, contrariando o Código Florestal Brasileiro (Lei 12.651/2012). O poder público estadual e municipal contribuem para o quadro de degradação ao efetuar aberturas de estradas sem os cuidados necessários para estabilização dos taludes. Observa-se também a ausência de legislação (Parcelamento, Zoneamento e Uso e Ocupação) que respalde o processo de monitoramento, fiscalização e controle da expansão urbana e das atividades agrícolas em alguns municípios. Apesar dos municípios da área de estudo (Irauçuba, Itapajé, Itapipoca, Pentecoste, Tejuçuoca, Trairi, Tururu, Umirim e Uruburetama) disporem de órgão gestor de meio ambiente, suas atuações ocorrem de forma deficitária seja por falta de recursos técnicos, financeiros e humanos, ou pelo fato de existirem conflitos de interesses ao desempenharem suas atividades integradas a outras secretarias, como agricultura, recursos hídricos, pesca, cultura e turismo.

Palavras-chave: Intervenções antrópicas; Degradação ambiental; Sustentabilidade 


\begin{abstract}
The various interventions in the Uruburetama Massif have generated a situation of degradation that compromises local economic, social and environmental sustainability. As a way of warning about the worsening of environmental problems, this research aims to make a diagnosis of environmental degradation in the humid hillside of the Uruburetama Massif / CE and its surroundings, in order to assess the impacts generated from human actions. The research methodology consisted of data acquisition, with a bibliographic review, orbital images and vector data obtaining; and carrying out field activities to recognize and identify land use and occupation and its associated impacts. Subsequently, these data and actions supported the characterization and thematic mapping of the research area. From the integration of these data, it was verified that the humid slope of the Uruburetama Massif has an advanced stage of degradation from the urban expansion and agricultural activities. The interventions occur even in the areas of permanent preservation, contrary to the Brazilian Forest Code (12.651 / 2012 Law). The state and municipal public authorities contribute to the degradation situation by making road openings without the necessary care to stabilize the slopes. There is also the absence of legislation (Installment, Zoning and Use and Occupation) that supports the process of monitoring, inspection and control of urban expansion and agricultural activities in some municipalities. Although the municipalities in the study area (Irauçuba, Itapajé, Itapipoca, Pentecoste, Tejuçuoca, Trairi, Tururu, Umirim and Uruburetama) have an environmental management body, their actions occur in a deficient manner due to lack of technical, financial and human resources, or because there are conflicts of interest when carrying out their activities integrated with other departments, such as agriculture, water resources, fishing, culture and tourism.
\end{abstract}

Keywords: Anthropic interventions; Environmental degradation; Sustainability

\title{
1 INTRODUÇÃO
}

O crescimento da população verificado no estado do Ceará nas últimas décadas acarretou em várias intervenções sobre os recursos naturais. As formas de uso e ocupação processadas no meio urbano e rural, promovidas pela população local, estimada em 9.132.078 pessoas (IBGE, 2018), vêm desencadeando problemas de diversas ordens que comprometem o desenvolvimento econômico e a sustentabilidade ambiental.

Dos 184 municípios cearenses, 175 estão inseridos no domínio do clima semiárido, o que representa 98,7\% do território estadual (BARBOSA, 2017). Nesse contexto, marcado por temperaturas elevadas e médias pluviométricas anuais inferiores a $800 \mathrm{~mm}$, se sobressaem os municípios que apresentaram, dentro de um contexto histórico, maior dinamismo econômico e que por sua vez atuam como polos de desenvolvimento e atração populacional, como por exemplo: Juazeiro do Norte, Sobral e alguns municípios da região metropolitana de Fortaleza.

Por outro lado, em meio a escassez de recursos hídricos, que limita o desenvolvimento dos sertões cearenses, se destacam os enclaves úmidos e subúmidos, 
considerados paisagens de exceção no contexto semiárido por apresentarem características distintas em relação ao seu entorno, como as serras de Uruburetama, Baturité, Maranguape, Aratanha e Meruoca; o Planalto da Ibiapaba e a Chapada do Araripe.

Essas áreas se distribuem de modo disperso pelos sertões semiáridos e se configuram como superfícies topograficamente elevadas de relevo serranos, com dimensões variadas e que são submetidos às influências de mesoclimas de altitude. Representam verdadeiras "ilhas verdes" no domínio morfoclimático das caatingas que recobrem as depressões interplanálticas e intermontanas semiáridas (AB'SÁBER, 1974).

Os enclaves úmidos ou brejos de altitude constituem importantes setores de produção agrícola, sendo tradicionalmente considerados como celeiros dos espaços sertanejos. A atividade agrícola tende a se concentrar, preferencialmente, nos topos e nas encostas úmidas, onde o potencial natural permite uma exploração diversificada e contínua do solo (SOUZA; OLIVEIRA, 2006).

Contudo, as diversas intervenções humanas efetuadas nessas áreas têm gerado um quadro de degradação que compromete o equilíbrio ambiental e a sustentabilidade agrícola. Vários setores das serras foram completamente desconfigurado pelas atividades agrícolas e extrativistas, ou pelo crescimento urbano, que em muitos casos esteve associado a exploração turística desses ambientes a partir da construção de pousadas, hotéis e casas de veraneio.

Chama atenção o fato de muitas dessas intervenções ocorrerem em desacordo com as prescrições legais. Assim, é possível observar supressão indiscriminada da vegetação, construções em áreas de preservação permanente, uso do fogo na prática agrícola, inserção de culturas inadequadas as características ambientais das serras, como a banana, e uso descontrolado dos sistemas de irrigação. Associadas a essas ações podem ser observadas a intensificação dos processos erosivos, o desencadeamento de movimento de massa, a ampliação das áreas de riscos, o assoreamento dos corpos d'água e a diminuição ou perda da produtividade agrícola. 
A partir do exposto, esta pesquisa objetiva realizar um diagnóstico da degradação ambiental na vertente úmida do Maciço de Uruburetama/CE e seu entorno, com intuito de analisar os impactos gerados a partir das ações antrópicas.

\section{MATERIAIS E MÉTODOS}

Os materiais e métodos utilizados nessa pesquisa estão apresentados no fluxograma da Figura 1, que está dividido em três etapas:

A primeira consistiu na aquisição dos dados. Neste momento também foram realizadas a revisão bibliográfica que fundamentou a pesquisa e as atividades de campo voltadas para reconhecimento da área de pesquisa e levantamento dos impactos gerados a partir do uso e ocupação. Para otimizar o levantamento, em virtude da grande extensão da área, e observar áreas de difíceis acesso ou de acesso restrito, foi utilizada uma Aeronave Remotamente Pilotada (ARP) Phantom 4.

Figura 1 - Fluxograma da metodologia empregada

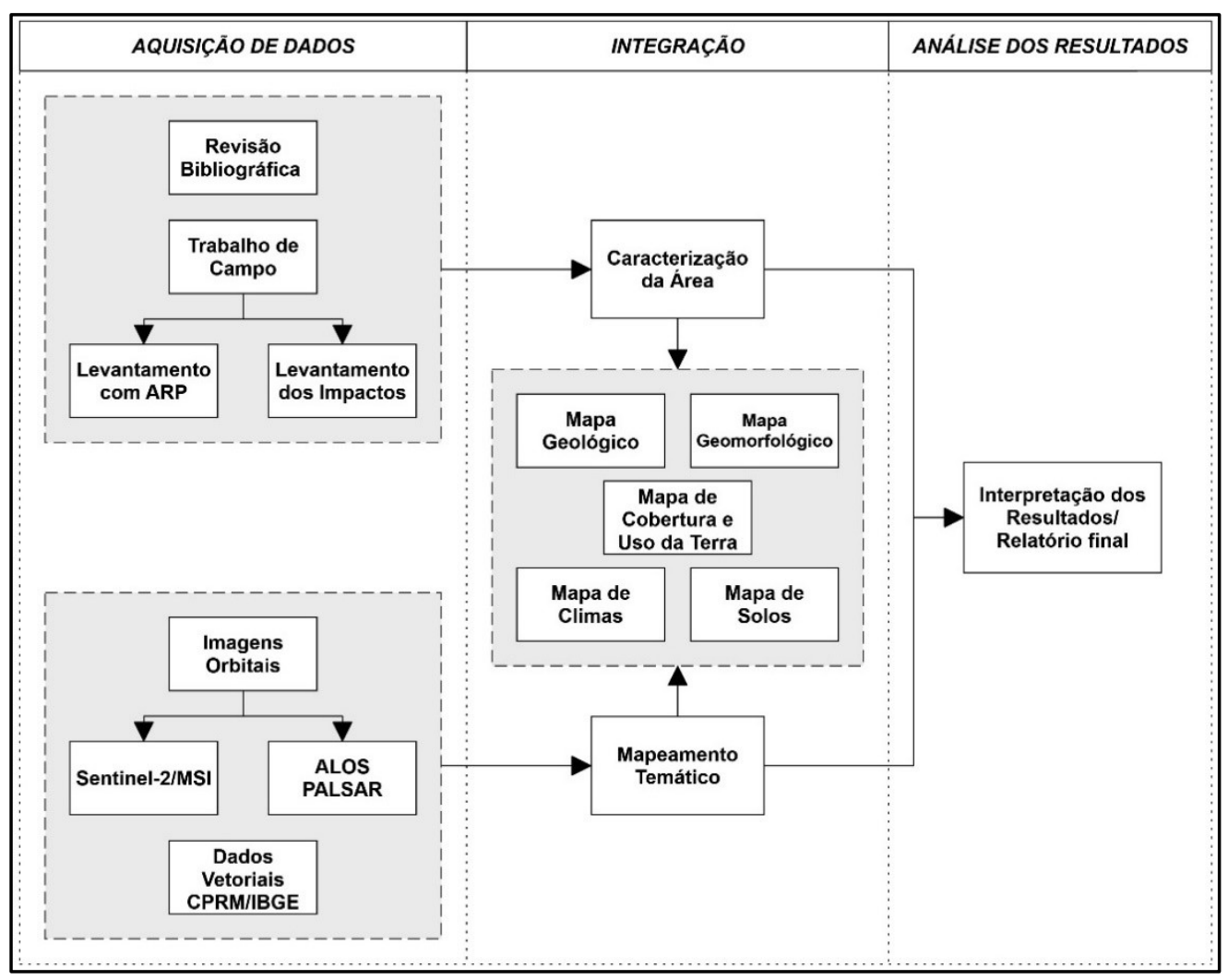


Ainda nessa etapa foram obtidas as imagens MSI/Sentinel-2, datada de 26 de setembro de 2017, no site do United States Geological Survey (2018) e o Modelo Digital de Elevação (MDE) ALOS PALSAR com resolução espacial de 12,5m, de 8 de março de 2011, da Agência de Exploração Aeroespacial do Japão (JAXA), disponível no sítio eletrônico Alaska Satellite Facility. Assim como foram adquiridos arquivos vetoriais de rodovias (IPECE), drenagem, sedes municipais, geologia, falhas, lineamentos (CPRM), limites municipais e solos (IBGE), entre outros, que subsidiaram o mapeamento temático.

A segunda compreendeu a integração dos dados anteriormente obtidos. Foi realizada a caracterização da área de estudo a partir das atividades de campo e das imagens geradas por ARP. O reconhecimento e a caracterização da área deram suporte a elaboração dos mapas temáticos de Geologia, Geomorfologia, Tipos Climáticos, Solos e Cobertura e Uso da Terra no software ArcGIS 10.5.

O mapa de Geologia foi adaptado de Cavalcante (2003) a partir dos dados vetoriais representativos da Geologia da área de estudo. O mapa de Geomorfologia e de Tipos climáticos foram adaptados de Silva (2007) tendo como suporte ao mapeamento o MDE ALOS PALSAR e a imagem MSI/Seninel-2. O mapa de Solos foi adaptado do IBGE (2017) a partir dos dados vetoriais das unidades de solos disponível na base de dados do site do órgão. Enquanto o Mapa de Cobertura e Uso da Terra foi adaptado do mapeamento realizado por Freires et al. (2019).

O mapa de cobertura e uso da terra foi obtido por classificação supervisionada por região do Índice de Vegetação por Diferença Normalizada (NDVI), gerado através das bandas do vermelho (4) e infravermelho próximo (8) da Imagem MSI/Sentinel-2, no software SPRING 5.5.3 (INPE, 2018). As classes temáticas foram definidas a partir o mapa fitoecológico do IPECE, do mapa de cobertura vegetal e uso da terra da Serra de Uruburetama de SILVA (2007) e do reconhecimento da área de estudo através das atividades de campo. Foram definidas as seguintes classes: Mata Úmida, Mata 
Seca, Caatinga Arbustiva Densa, Caatinga Arbustiva Aberta, Cultivos, Corpos D'água e Urbano/Solo Exposto.

Na terceira, a partir da integração dos dados, houve a interpretação dos resultados e foi elaborado o relatório final.

\section{RESULTADOS E DISCUSSÃO}

\subsection{Localização da área de estudo}

"A serra de Uruburetama, posicionada a aproximadamente $100 \mathrm{~km}$ a oeste de Fortaleza, consiste num maciço montanhoso de formato circular, sendo um pouco alongado na direção E-W" (BRANDÃO; FREITAS, 2014). "Mostra-se intensamente dissecada em colinas e cristas, com vales superimpostos, em forma de $V$, segundo uma disposição paralela e orientada a NW-SE" (BRANDÃO, 2003).

A serra está situada na porção setentrional do estado do Ceará e trata-se de um maciço residual com cerca de $1000 \mathrm{~km}^{2}$ de área. Compreende parte dos Municípios de Uruburetama, Irauçuba, Itapipoca, Itapajé e Umirim. A porção úmida/subúmida da serra corresponde às encostas norte-oriental e à superfície de cimeira (platô da serra). O maciço é fortemente tectonizado e intensamente fraturado, em que em muitos casos, a rede de drenagem se adapta a essas estruturas (SOUZA; OLIVEIRA, 2006).

A área de estudo compreende a vertente úmida da serra de Uruburetama e adjacências, totalizando 1.342,73 Km². Localiza-se entre as coordenadas UTM (zona 24 Sul) 9.619.380 m e 9.577.181 m N; 424.667 m e 456.494, m E, está inserida, em diferentes proporções, dentro do limite administrativo de nove municípios do estado do Ceará (Figura 2), que são: Irauçuba, Itapajé, Itapipoca, Pentecoste, Tejuçuoca, Trairi, Tururu, Umirim e Uruburetama. 
Figura 2 - Mapa de localização da área de estudo

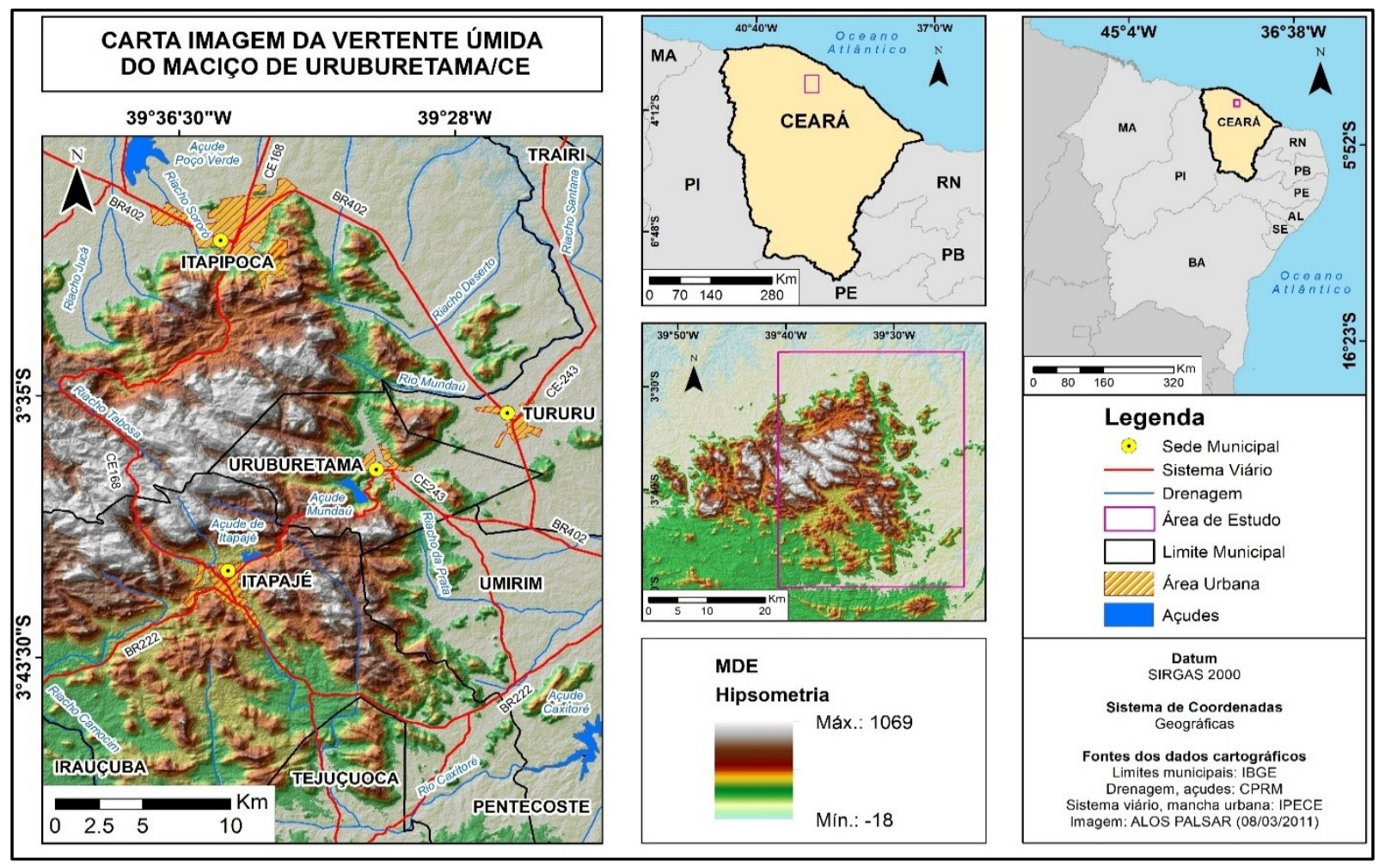

\subsection{Características físico-geográficas}

\subsubsection{Geologia/Geomorfologia}

Localizada na província da Borborema, a área de estudo apresenta-se formada em quase sua totalidade por rochas do Complexo Nordestino, formação cronologicamente pertence ao Pré-Cambriano do inferior-médio (OLIVEIRA, 2002). Esta unidade, como pode ser observado na Figura 3, por sua vez, se subdivide em Suíte Intrusiva Tamboril-Santa Quitéria, Complexo Ceará - Unidade Canindé e Complexo Ceará - Unidade Independência. As unidades de menor abrangência são as litologias cenozoicas da Formação Barreiras, encontrada a nordeste do maciço, e os depósitos quaternários de origem aluvial e colúvio-aluvial, que se encontram distribuídos em diferentes setores da área de pesquisa, onde predominam processos de sedimentação. 
A Suíte Intrusiva Tamboril-Santa Quitéria é a unidade litoestratigráfica mais representativa da área de estudo, se entendendo de Leste a Oeste e de Norte a quase ao Sul do local. Conforme Schobbenhaus e Neves (2003), essa unidade, formada na Era Neoproterozóica (1,0 Ga - 540 Ma), é composta por rochas plutônica félsicas a intermediárias.

Conforme Cavalcante et al. (2003), a Suite Intrusiva é formada pela associação granito-migmatítica, envolvendo granitóides neoproterozóicos, cinzentos e rosados, de granulação variável até termos porfiríticos, gnaissificados ou não, em jazimentos de geometrias e dimensões diversas; para e ortognaisses migmatíticos, além de rochas calcissilicáticas, anfibolitos e, localmente, rochas ferríferas e metaultramáficas.

Conforme Schobbenhaus e Neves (2003), as unidades Canindé e Independência do Complexo Ceará, datam do Paleoproterozóico (2,5 - 1,6 Ga), sendo formadas por rochas para e/ou ortoderivadas de grau médio a alto.

A Unidade Canindé ocorre ao sul da área de estudo. É formada por paragnaisses em níveis distintos de metamorfismo-migmatização, incluindo ortognaisses ácidos e rochas metabásicas: metagabros, anfibolitos com ou sem granada, e gnaisses dioríticos, associados ou não a enderbitos; metagabros e metaultramáficas serpentinizadas e xistificadas, lentes de quartzitos, metacalcários, rochas calcissilicáticas, formações ferríferas e ferro-manganesíferas, além de metaultramáficas; granulitos máficos, enderbitos e leptinitos; anfibólio gnaisses e/ou anfibolitos (CAVALCANTE et al., op. cit.).

A Unidade Independência, ocorre em porções bem restritas, podendo ser observado no extremo Sudeste e Sudoeste da área de estudo. Segundo Cavalcante et al. (op. cit.), sua litologia é formada por paragnaisses e micaxistos aluminosos (em parte migmatíticos), incluindo quartzitos, metacalcários, rochas calcissilicáticas e, mais raramente, anfibolitos. 
Figura 3 - Mapa Geológico da área de estudo

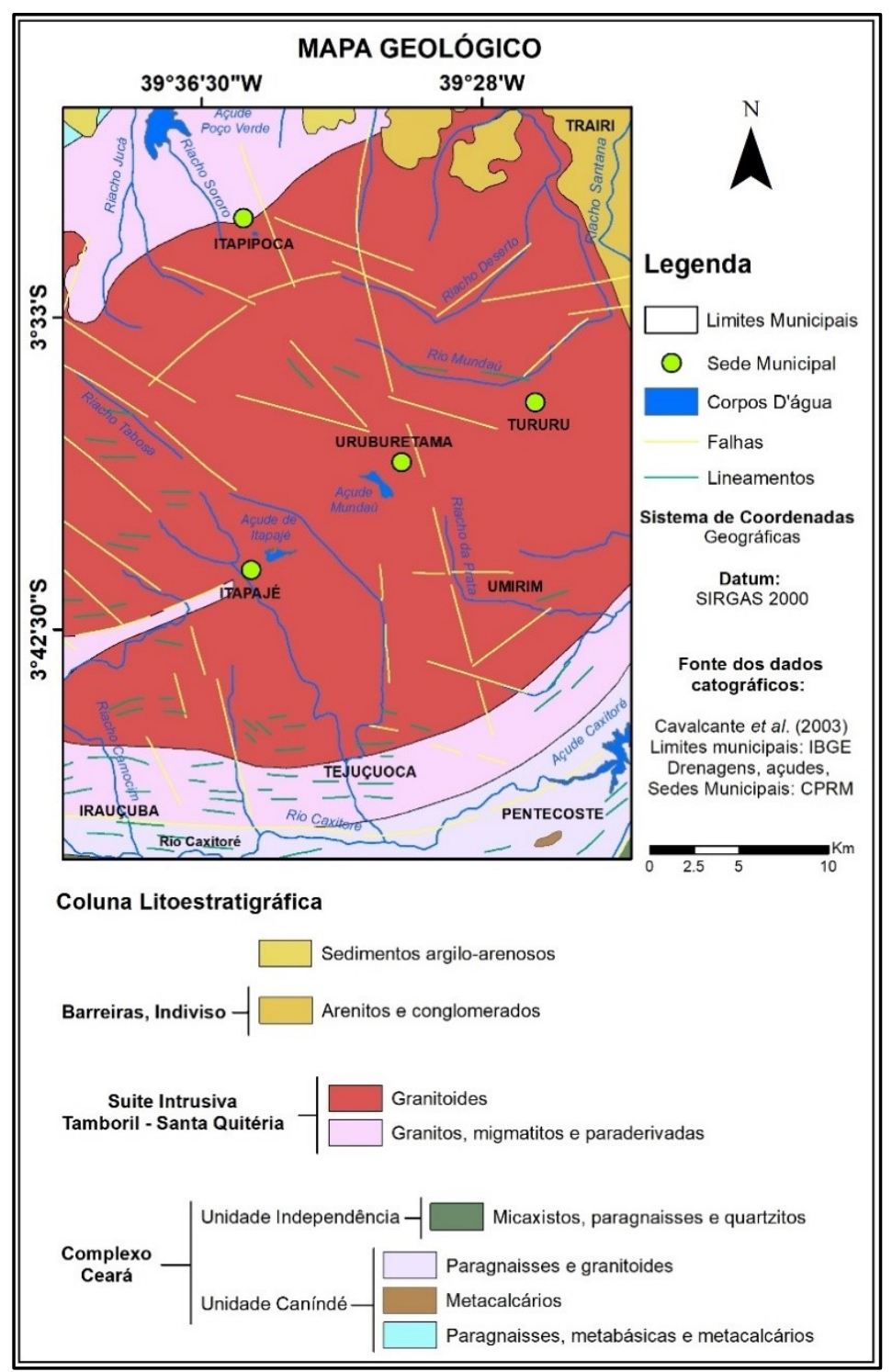

Fonte: Cavalcante et al. (2003)

O Grupo Barreira Indiviso, de idade Plio-plestocênica ocorre a Nordeste da área de estudo. É formada por arenitos argilosos de tonalidade variada (amarelada, avermelhada e esverdeada), matriz argilo-caulínica, com cimento argiloso, ferruginoso e, às vezes, silicoso; granulação fina a média, com leitos conglomeráticos e nódulos lateríticos na base. Apresenta sistema fluvial com esporádicas corridas de lamas (CAVALCANTE et al., op. cit.).

Os Depósitos aluviais são formados por argilas, areias argilosas, quartzosas e quartzofeldspáticas, conglomeráticas ou não, cascalhos e argilas orgânicas / fluvial, em parte com influência marinha (CAVALCANTE et al., op. cit.). No sopé do maciço ocorrem na forma de depósitos coluviais, que são compostos por materiais mal selecionados 
resultantes dos processos de esculturação (erosão, movimento de massa, enxurradas) que ocorrem nas encostas.

De acordo com Cavalcante et al. (op. cit.), as litologias e/ou associações estão distribuídas na área de pesquisa conforme a Figura 3. Podendo ser observados arenitos e conglomerados; granitos, migmatitos e paraderivadas; granitóides; metacalacários; micaxistos, paragnaisses e quartzitos; paragnaisses e granitóides; paragnaisses, ortognaisses, metabásicas e metalcalcários; e sedimentos argilo-arenosos.

Morfologicamente a área estudada apresenta as seguintes unidades: Tabuleiro Prélitorâneo, Superfície Pediplanada (Depressão Sertaneja), Maciço Residual, Cristas Residuais e Inselbergs, Planícies Fluviais e as Planícies Alveolares (Figura 4).

Figura 4 - Mapa geomorfológico da área de estudo.

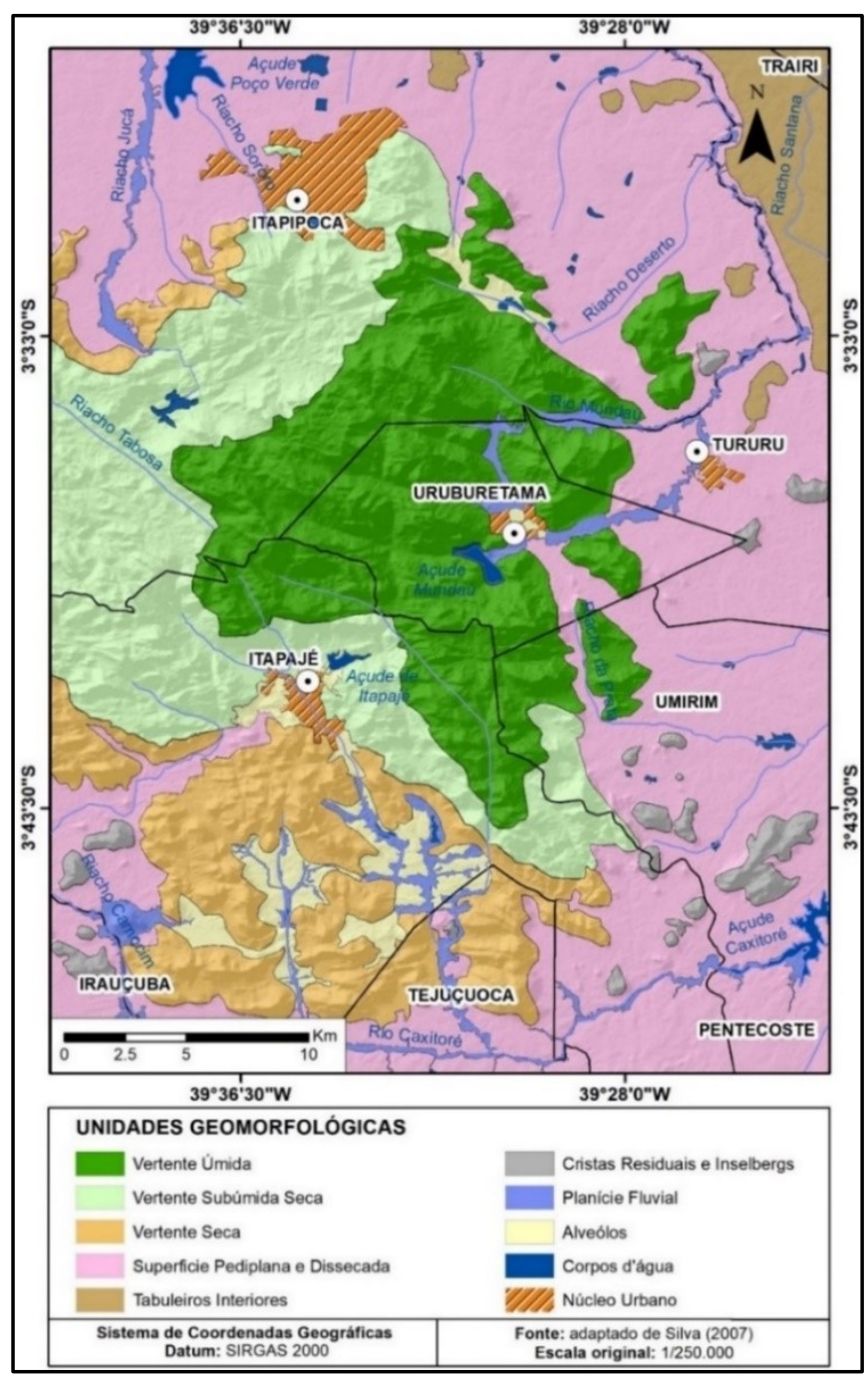

Fonte: adaptado de Silva (2007) 
O grupo Barreiras corresponde geomorfologicamente aos Glacis de Deposição Prélitorâneos ou Tabuleiros Pré-litorâneo. Conforme Souza (2000) esse tipo de relevo apresenta inclinação suave em direção ao mar com declives de angulação inferior a $5^{\circ}$, sendo recobertos por sedimentos areno-argilosos fracamente dissecados em interflúvios tabulares.

Segundo Brandão (1995) a Formação Barreiras está distribuída numa faixa de largura variável, disposta paralelamente à linha de costa e à retaguarda dos sedimentos eólicos antigos e atuais. É formada litologicamente por sedimentos areno-argilosos, não ou pouco litificados, de coloração avermelhada, creme ou amarelada, muitas vezes de aspecto mosqueado, com granulação variando de fina a média e contendo intercalações de níveis conglomeráticos. Sua origem é predominantemente continental, onde os sedimentos foram depositados sob condições de um clima semiárido, sujeito a chuvas esporádicas e violentas, formando amplas faixas de leques aluviais coalescentes. Durante esta época, o nível do mar era mais baixo que o atual proporcionando o recobrimento de uma ampla plataforma de deposição.

A drenagem apresenta um fluxo muito lento, limitando a capacidade de incisão linear, no que resulta em baixa amplitude altimétrica, não superior a $15 \mathrm{~m}$, entre o topo dos tabuleiros e os fundos dos vales (SOUZA, 2000).

As encostas com caimento para as planícies fluviais possuem feições retilíneas que expõem, eventualmente, material ferralítico. Grande parte dos tabuleiros é recoberta por espessa cobertura arenosa, da ordem de 1,5-2,0 m. Em porções esparsas, a cobertura superficial apresenta maior percentagem de argila. Isto contribui para uma dissecação incipiente do relevo que contrasta com os topos horizontais das áreas recoberta pelas areias (SOUZA, 2000).

De acordo com Souza (2000, p.22), “Os Tabuleiros Pré-litorâneos ficam situados à retaguarda do cordão de dunas, contatando, sem ruptura topográfica, com depressões sertanejas".

As Depressões Sertanejas (Figura 5) são marcadas por topografias planas ou levemente onduladas, apresentando altitudes médias entre 130 e $150 \mathrm{~m}$. Em altitudes superiores a $300 \mathrm{~m}$ a dissecação é mais evidente, isolando interflúvios de feições colinosas, tabuliformes ou lombadas e constituem os níveis elevados desta unidade (SOUZ.A, 2000). 
Figura 5 - Depressão sertaneja e inselbergs no município de Tururu

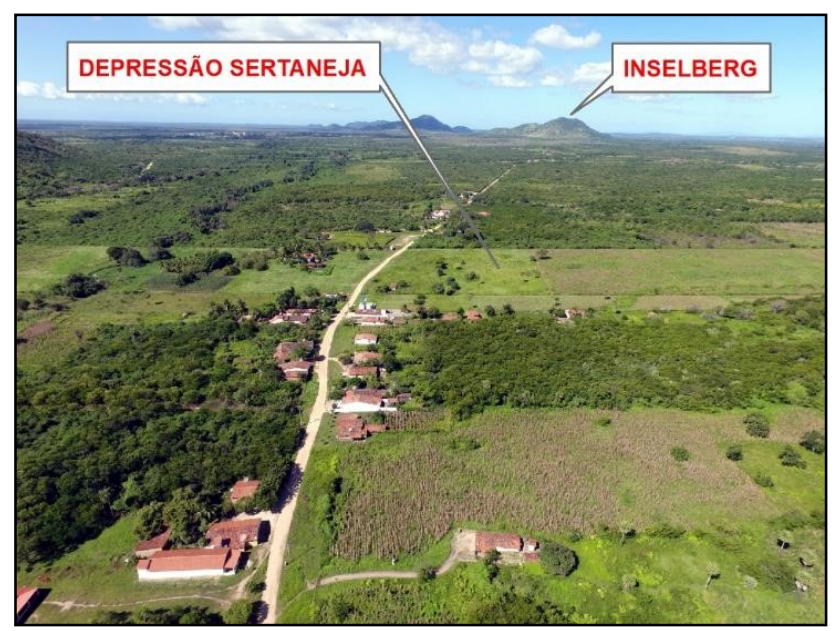

Foto: Daniel Gomes (obtida por ARP, 21/05/2017)

De acordo com Souza (2000), a morfologia da depressão sertaneja se expõe através dos pedimentos que se inclinam desde a base dos maciços residuais, dos planaltos sedimentares e dos inselbergs. O caimento topográfico é feito no sentido dos fundos de vales e do litoral.

Dentre as características que individualizam o compartimento em análise, podem ser destacadas: acentuadas variações litológicas, truncamento indistinto das litologias por processos de morfogênese mecânica, revestimento generalizado por caatingas que possuem pequena espessura do manto de alteração das rochas, ocorrência frequente de pavimentos e paleopavimentos, deficiente capacidade de erosão linear em face da intermitência sazonal dos cursos d'água, justificando a pequena amplitude altimétrica entre os interflúvios e os fundos dos vales, ocorrência dispersa de inselbergs e cristas residuais nos setores de maior resistência litológica, desenvolvimento de áreas de acumulação inundáveis a jusante das rampas pedimentadas (SOUZA, 2000).

Apesar da complexidade litológica, as depressões sertanejas compõem superfícies de aplainamento onde o trabalho erosivo truncou indistintamente, os mais variados tipos de rochas. Este trabalho não invalida o trabalho de erosão diferencial, destacando rochas mais resistentes, rebaixando ou dissecando os setores de litologias tenras. Campos de Inselbergs, cristas quartzíticas dispersas e maciços 
rebaixados são exemplos da ação seletiva dos processos degradacionais (SOUZA, 2000).

Conforme Brandão (2003), as cristas e inselbergs se formam nos setores de maior resistência litológica e se destacam no contexto aplainado das superfícies de pedimentação.

A serra de Uruburetama se apresenta como um bloco compacto com quase 1000 $\mathrm{km}^{2}$ de área formada em rochas do complexo migmátitico. As formas interfluviais com colinas e cristas tem orientação NW-SE com vales superimpostos em disposição transversal. Em inúmeros setores o padrão de drenagem é retangular, com forte controle estrutural. A regra, no entanto, é o predomínio de padrões dentríticos e subdentríticos na rede hidrográfica. Nas encostas que limitam o maciço é comum observar passagens de pedimentação que se posicionam ao nível das depressões sertanejas, isolando esporões e inselbergs (SOUZA, 2000).

De acordo com Souza e Oliveira (2006) a altimetria média no Maciço de Uruburetama é de aproximadamente $750 \mathrm{~m}$. Seu relevo é dissecado em cristas, colinas e lombas alongadas, que se alternam com vales em forma de $V$ e planícies alveolares (Figura 6). Em áreas de maior umidade prevalecem as formas de topos convexos, com vertentes curtas e declives que variam de $10 \%$ a 30\%. As cristas apresentam feições simétricas, com vertentes retilíneas e compridas. Os declives são mais íngremes e maiores do que $30 \%$. Conforme Brandão e Freitas (2014) as cristas mais elevadas atingem 800 a 900 metros de altitude.

De acordo com Christofoletti (1981), os vales com perfil em forma de V indicam uma relação equilibrada entre o entalhamento e o alargamento. E geralmente são esculpidos em material homogêneo e as vertentes são simétricas.

Conforme Brandão (2003) e Silva (2007), o Maciço de Uruburetama tem suas vertentes subdivididas em vertente seca, subúmida seca e úmida. Essa compartimentação se dá a partir de parâmetros como: simetria, profundidade do vale, distância entre os interflúvios, declividade e principalmente pelo aspecto climático regente. 
Figura 6 - Relevo dissecado no município de Uruburetama

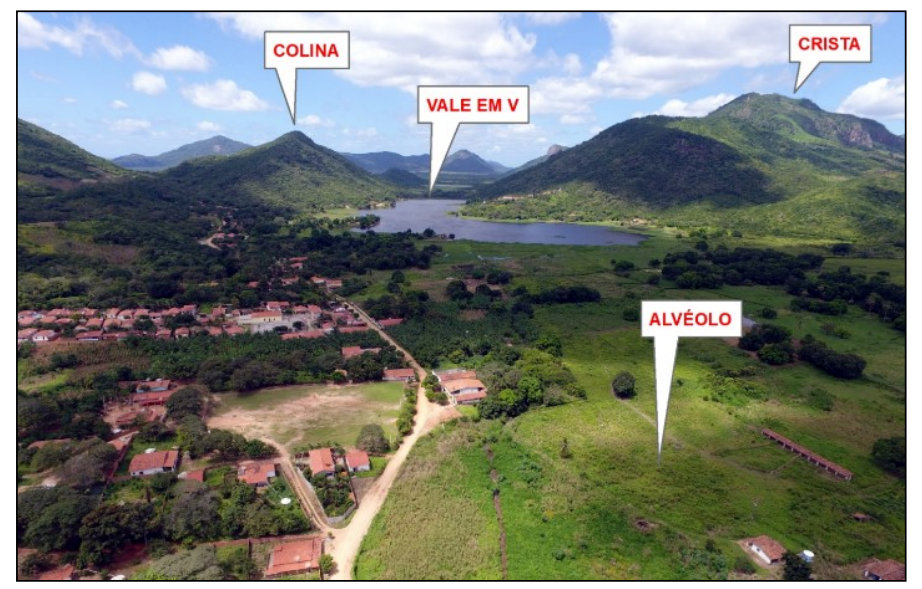

Foto: Daniel Gomes (obtida por ARP, 21/05/2017).

Os vales são entalhados por uma rede de drenagem que exibe um forte controle estrutural. Nas áreas onde ocorre suavização topográfica, a diminuição do gradiente implica no predomínio dos processos de sedimentação. Que por sua vez, favorecem o desenvolvimento das planícies alveolares que são recobertas por sedimentos aluviais e coluviais (SOUZA; OLIVEIRA 2006).

De acordo com Guerra e Guerra (1997), os alvéolos são planícies intermontanas, formadas por secções alargadas de um vale, geralmente entulhada de sedimentos a partir do recuo das vertentes.

As planícies fluviais estão distribuídas de forma dispersa nos setores de superfície aplainada, formando depósitos aluvionares que bordejam o leito dos principais rios, como Mundaú, Caxitoré e Jucá.

\subsubsection{Aspectos Hidroclimáticos}

O clima influência diretamente as plantas, os animais, o ser humano e o solo. Influencia também as rochas através do intemperismo, enquanto as forças externas que modelam a superfície da Terra são basicamente controladas pelas condições climáticas. Por outro lado, o clima, particularmente perto da superfície, é influenciado pelos elementos da paisagem, da vegetação e pelas atividades humanas. Os processos geomorfológicos, pedológicos e ecológicos, e as formas que eles originam, só podem ser 
devidamente compreendidos com referência ao clima predominante na atualidade e no passado (AYOADE, 2015).

O clima influência a maior parte dos processos naturais que ocorrem na superfície terrestre. Os condicionantes atmosféricos e climáticos promovem ajustamentos nos diversos elementos da paisagem: relevo, solo, vegetação, recursos hídricos e, principalmente, na vida humana. O conhecimento dos eventos atmosféricos e de suas implicações é de suma importância para o planejamento territorial e para implementação de medidas que contemplem o homem e o meio ambiente (BRANDÃO, 1995).

O estado do Ceará está inserido no domínio do clima semiárido, predominante na região Nordeste do país. Esse clima caracteriza-se pelo baixo índice pluviométrico e pela sua má distribuição espacial e temporal. Pode ser identificado por dois períodos: um úmido, com chuvas irregularmente distribuídas no espaço ao longo de um curto período, e outro seco e longo, marcado pela ausência de chuvas, podendo se prolongar por mais de um ano e provocar o fenômeno da seca.

Conforme Fernandes $(2003,2006)$, a região nordeste aparece como uma área de convergência das terminações de quatro fluxos de correntes atmosféricas perturbadas: correntes perturbadas do sul, correntes perturbadas do norte, correntes perturbadas do leste e correntes perturbadas do oeste. Contudo as correntes perturbadas do norte apresentam maior significado, sendo representadas pelos deslocamentos da Convergência Intertropical (CIT).

De acordo com Brandão (1995) e Morais (2000), existem três sistemas geradores de precipitações no estado do Ceará: A zona de convergência Intertropical (ZCIT), as frentes frias originárias do pólo sul, e um Centro de Vorticidade Ciclônica, cujo tempo de atuação varia de acordo com o período chuvoso. Podem ser apontados ainda, sistemas de menor escala que atuam na área: as linhas de instabilidade formadas ao longo da costa, e os efeitos da brisa marítima e terrestre que ocorrem com frequência na zona litorânea. 
“A zona de Convergência Intertropical (ZCIT) forma-se na área de baixas latitudes, onde o encontro dos ventos alísios provenientes de sudeste com os de nordeste cria uma ascendência das massas de ar, que são normalmente úmidas" (MENDONÇA; DANNIOLIVEIRA, 2007, P.90). “Ela se movimenta para o norte durante o verão, no hemisfério setentrional, e para o sul durante o verão no hemisfério meridional, estando sua posição média pouco acima do Equador" (AYOADE, 2015, P.125).

Segundo Morais (2000), entre os sistemas que controlam o regime pluvial no litoral do Estado do Ceará, a frente geradora de chuvas de maior importância é a ZCIT. Ao se movimentar para o hemisfério sul, até atingir seu ponto máximo no equinócio outonal (21 de março), é responsável pela ocorrência de chuvas de janeiro a abril. A partir de maio, quando a ZCIT começa seu retorno em direção ao hemisfério norte, as chuvas entram em declínio, tornando-se cada vez mais raras.

De acordo com Silva (2007), a precipitação na Serra de Uruburetama engloba características típicas de regime tropical com a máxima no outono e a mínima no inverno. No setor sul/oeste, a precipitação média anual é de 460 mm (sede municipal de Irauçuba). Apresenta geralmente três meses chuvosos concentrados no final do verão, começo do outono, entre os meses de fevereiro, março e abril. No setor norte/leste, a precipitação média anual é de $1.056 \mathrm{~mm}$ (sede de Uruburetama). Apresenta geralmente de seis a sete meses chuvosos, concentrados no primeiro semestre do ano. A temperatura média situa-se em torno de $21^{\circ}$ a $23^{\circ} \mathrm{C}$ nos platôs e na depressão circunjacente em torno de $26^{\circ}$.

"As condições climáticas permitem enquadrar o clima serrano como do tipo Aw' da classificação de Köppen. Trata-se de clima quente e úmido com chuvas de verão e precipitação máxima de outono" (SOUZA; OLIVEIRA, 2006).

Conforme o mapa de clima do Brasil elaborado pelo IBGE (2002), a serra de Uruburetama está inserida numa área de Clima Tropical de Zona Equatorial. Conforme Mendonça e Danni-Oliveira (2007), esse tipo climático se distribui por parte das regiões Norte e Nordeste e engloba todo estado do Ceará. 
“Esse clima se caracteriza por uma considerável variabilidade pluviométrica e térmica. A temperatura apresenta expressiva variabilidade espacial e temporal, mesmo que toda área esteja enquadrada no âmbito dos climas quentes" (MENDONÇA; DANNIOLIVEIRA, 2007, P.90). Assim, conforme o IBGE (2002), o Clima Tropical de Zona Equatorial pode ser dividido em subtipos climáticos.

De acordo com Silva (2007), os subtipos climáticos que ocorrem na serra de Uruburetama, consoante a classificação do IBGE (2002), são: tropical quente semiárido de seis meses secos, tropical quente semiárido de sete a oito meses secos, tropical quente semiárido de nove a dez meses secos (este não está inserido no recorte da área de estudo, Figura 8) e tropical quente semiúmido de cinco meses secos.

Figura 8 - Mapa de Tipos Climáticos da área de estudo

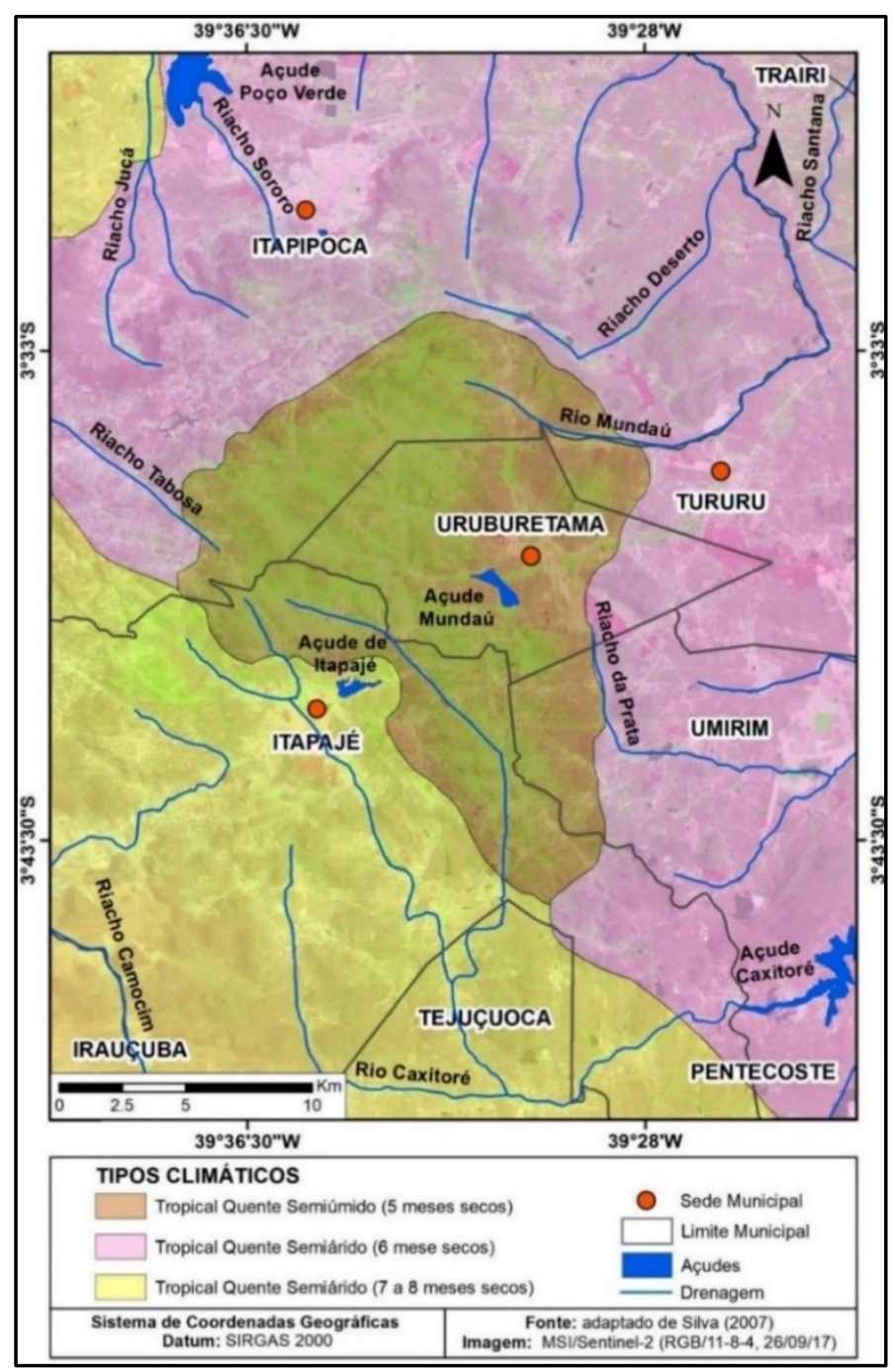

Fonte: adaptado de Silva (2007) 
"Sob o aspecto hidrológico, o Maciço de Uruburetama compõe o mais importante centro dispersor de drenagem da área centro-norte do Ceará. Três sistemas fluviais de caráter exorréico têm origem na área serrana: os sistemas dos rios Curu, Aracatiaçu e Mundaú" (SOUZA; OLIVEIRA, 2006).

Conforme Silva (2007) a serra de Uruburetama é um importante dispersor de drenagem de rios, como o Mundaú, e possui afluentes diretos ( $1^{\mathrm{a}}$ e $2^{\mathrm{a}}$ ordem) dos rios Caxitoré, Aracatiaçu, Missi, entre outros. A configuração da drenagem está disposta em duas bacias hidrográficas, ambas exorreicas: a do Curu e a do Litoral.

Os rios apresentam regimes sazonais e têm dependência direta da distribuição pluviométrica. Exceção aos rios cujas nascentes encontram-se na vertente úmida do maciço, que dispõe de maiores médias pluviométricas e, consequentemente, apresentam o regime perene, com redução do volume de água nos períodos de estiagem. Assim, a vertente úmida apresenta uma rede fluvial densa, com vales profundos e baixo potencial de águas subterrâneas, ao não ser nas áreas fortemente fraturadas.

De acordo com Silva (2007), os rios e riachos da bacia hidrográfica do Curu, dispostos na região serrana (parte norte do Município de Itapajé) são classificados em subsequentes.

Conforme Suguio e Bigarela (1979), estes rios apresentam sentido de fluxo controlado pela estrutura rochosa, sempre acompanhando zonas de fraqueza, tais como falhas, diaclasamento, rochas menos resistentes, etc. Enquanto na área da superfície pediplanada desta bacia, os rios são classificados como insequentes, ou seja, segundo Suguio e Bigarela (op. cit.), são rios que não apresentam controle estrutural visível na disposição espacial da drenagem e que tendem a se desenvolver sobres rochas homogêneas representadas por sedimentos horizontais e por rochas ígneas. 
De acordo com Silva (op. cit.) a bacia hidrográfica do rio Curu apresenta um padrão de drenagem que poder ser classificado em dois tipos: subparalelo, que ocorre dentro da área serrana, e dentrítico, observado na área pediplanada.

Conforme Silva (op. cit.), os rios da bacia hidrográfica do Litoral podem ser classificados em consequentes, quando a drenagem ocorre na região serrana e os rios correm praticamente retilíneos em direção à baixada; e insequente, na superfície pediplanada. Quanto ao padrão de drenagem, a área serrana apresenta a forma dentrítico-retangular, enquanto a área pediplanada a drenagem é do tipo dentrítico.

Dentro das vertentes da serra de Uruburetama existem cerca de 50 nascentes que contribuem para alta densidade da drenagem. E esta, por sua vez, reflete a impermeabilidade do substrato rochoso, favorecendo a construção de barragens e açudes ao longo dos rios (SILVA, 2007).

Os principais açudes da região serrana são o Mundaú e o de Itapajé, também conhecido como Ipuzinho. Conforme o Departamento Nacional de Obras Contra a Seca/DNOCS (2018), o Açude Mundaú, cuja tomada de água se dá no rio de mesmo nome, no município de Uruburetama, tem capacidade para $21.308 .000 \mathrm{~m}^{3}$ de água. De acordo com a Secretaria de Recursos Hídricos do Estado do Ceará (2018) o Açude Ipu tem sua barragem construída no leito do riacho Escorado, no município de Itapajé, e apresenta capacidade para $4.850 .000 \mathrm{~m}^{3}$.

Na depressão sertaneja o principal açude é o Caxitoré, localizado no município de Pentecoste. Segundo o DNOCS (2018), a barragem erguida no rio Caxitoré, afluente do rio Curu, forma um lago com uma superfície de cerca 4.574 ha e um volume de acumulação de $202.000 .000 \mathrm{~m}^{3}$.

Na Bacia do Litoral se destaca o açude Poço Verde, no município de Itapipoca. De acordo com a SRH/CE (2018), o Poço Verde tem capacidade para $13.650 .000 \mathrm{~m}^{3} \mathrm{e}$ uma extensão de 410 ha. 
De acordo com Souza e Oliveira (2006), as águas subterrâneas apresentam baixas condições potenciais e de utilização em decorrência da preponderância de rochas do embasamento cristalino, que em função de sua impermeabilidade, não favorece a formação de bons aquíferos. Em áreas mais fortemente fraturadas há melhoria de disponibilidade hidrogeológica.

Segundo Souza e Oliveira (op.cit.), a rede de fraturas é normalmente preenchida por sedimentos que são carreados pelas ações das chuvas e enxurradas. Consequentemente, as fraturas ficam seladas e, as águas que nelas circulam não atingem as eventuais reservas de águas subterrâneas, exceto em quantidade insignificante.

“Nos setores de planícies alveolares e das pequenas depressões com coberturas colúvio-aluvionares há maior disponibilidade das águas subterrâneas em função da maior porosidade e permeabilidade dos terrenos" (SOUZA; OLIVEIRA, 2006).

\subsubsection{Solos e cobertura vegetal}

De acordo com Palmieri e Larach (2004) o solo é constituído por corpos naturais tridimensionais, que resultam da ação integrada do clima e organismos sobre o material de origem, condicionado pelo relevo em diferentes períodos de tempo, o qual apresenta características associadas aos processos e mecanismos dominantes na sua formação.

Na área de estudo, conforme o IBGE (2017), são identificados os seguintes tipos de solos: Argissolo Vermelho - Amarelo Eutrófico, Neossolo Litólico Eutrófico, Neossolo Quartzarênico Órtico, Neossolos Regolítico Distrófico, Planossolo Háplico Eutrófico e Luvissolo Crômico Órtico. A distribuição espacial de cada classe de solo pode ser observada na Figura 9. 
Figura 9 - Mapa de distribuição de solos da área de estudo

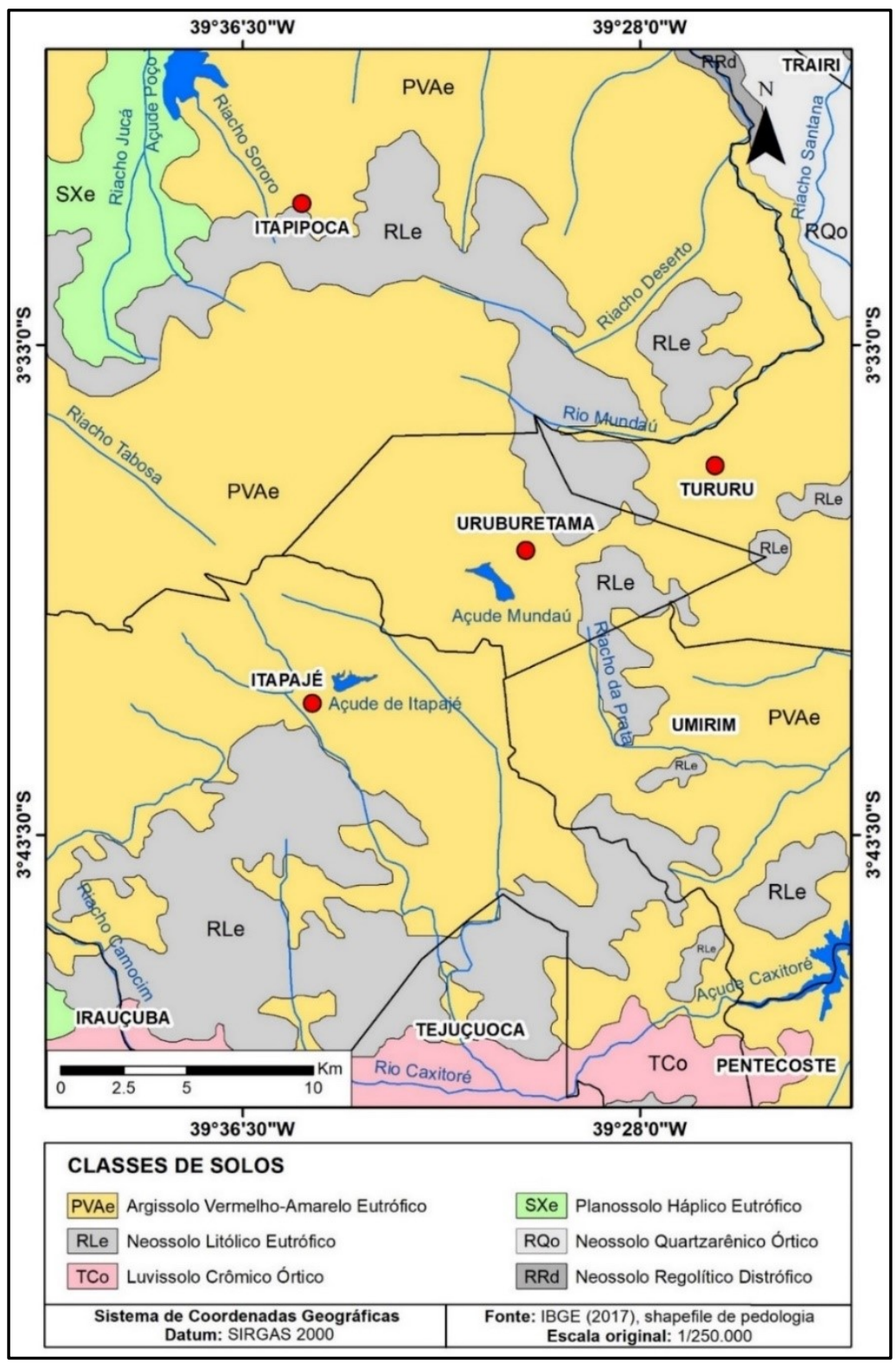

Fonte: IBGE (2017)

O Argissolo Vermelho - Amarelo Eutrófico é o solo de maior abrangência na área. Os argissolos são constituídos por material mineral, que têm como características diferenciais a presença de horizonte $B$ textural de argila de atividade baixa, ou alta conjugada com saturação por bases baixa ou caráter alítico. O horizonte B textural (Bt) encontra-se imediatamente abaixo de qualquer tipo de horizonte superficial, exceto o hístico, sem apresentar, contudo, os requisitos estabelecidos para serem enquadrados nas classes dos Luvissolos, Planossolos, Plintossolos ou Gleissolos (EMBRAPA, 2009). “As cores do horizonte Bt variam de acinzentadas a avermelhadas e as do horizonte $A$, são 
sempre mais escurecidas. A profundidade dos solos é variável, mas em geral são pouco profundos e profundos" (IBGE, 2007).

Os Neossolos representam a segunda maior abrangência na área. Estes solos são constituídos por material mineral, ou por material orgânico pouco espesso, que não apresentam alterações significativas em relação ao material originário devido à baixa intensidade de atuação dos processos pedogenéticos, seja em razão de características inerentes ao próprio material de origem, como maior resistência ao intemperismo ou composição química, ou dos demais fatores de formação (clima, relevo ou tempo), que podem impedir ou limitar a evolução dos solos. (EMBRAPA, 2009). Os neossolos são representados pelas seguintes variações na área de estudo: Neossolos Litólicos Eutróficos, Neossolos Quartzarênicos, Neossolos Regolíticos.

O Neossolo Litólico Eutrófico pode ser encontrado, sobretudo, nos inselbergs no entorno do maciço. São Solos com horizonte A ou hístico, assentes diretamente sobre a rocha ou sobre um horizonte $\mathrm{C}$ ou $\mathrm{Cr}$ ou sobre material com $90 \%$ (por volume), ou mais de sua massa constituída por fragmentos de rocha com diâmetro maior que $2 \mathrm{~mm}$ (cascalhos, calhaus e matacões) e que apresentam um contato lítico típico ou fragmentário dentro de $50 \mathrm{~cm}$ da superfície do solo. Admite um horizonte B em início de formação, cuja espessura não satisfaz a qualquer tipo de horizonte B diagnóstico. Esse tipo de solo apresenta saturação por bases alta, com V $\geq 50$ \% (EMBRAPA, 2009).

O Neossolo Quartzarênico Órtico, é observado na porção nordeste da área de pesquisa sobre o Tabuleiro Pré-litorâneo. O Neossolo Quartzarênico é um solo sem contato lítico dentro de $50 \mathrm{~cm}$ de profundidade, com sequência de horizontes A-C, porém apresentando textura areia ou areia franca em todos os horizontes até, no mínimo, a profundidade de $150 \mathrm{~cm}$ a partir da superfície do solo ou até contato lítico; são essencialmente quartzosos, tendo nas frações areia grossa e areia fina $95 \%$ ou mais de quartzo, calcedônia e opala e, praticamente, ausência de minerais primários alteráveis (EMBRAPA, 2009).

Conforme Souza et al, (2009) os Neossolos Quartzarênicos têm textura arenosa, são na maioria das vezes profundos, pouco desenvolvidos, excessivamente drenados e seu uso agrícola é limitado devido a sua baixa fertilidade natural. 
O Neossolo Regolítico Distrófico ocorre na porção nordeste da área de estudo, a noroeste do Neossolo Quartzarênico. É um Solo com contato lítico a uma profundidade maior que $50 \mathrm{~cm}$ e horizonte $\mathrm{A}$ sobrejacente a horizonte $\mathrm{C}$ ou $\mathrm{Cr}$, admitindo horizonte $\mathrm{Bi}$ com menos de $10 \mathrm{~cm}$ de espessura. Deve apresentar pelo menos um dos seguintes requisitos: $4 \%$ ou mais de minerais primários alteráveis (menos resistentes ao intemperismo) na fração areia total e/ou no cascalho, porém referidos a 100g de TFSA em algum horizonte dentro de $150 \mathrm{~cm}$ da superfície do solo; e/ou 5\% ou mais do volume da massa do horizonte $\mathrm{C}$ ou $\mathrm{Cr}$, dentro de $150 \mathrm{~cm}$ de profundidade, apresentando fragmentos de rocha semi-intemperizada, saprolito ou fragmentos formados por restos da estrutura orientada da rocha (pseudomorfos) que deu origem ao solo. Estes solos apresentam saturação por bases baixas, com $V<50 \%$ (EMBRAPA, 2009).

O Planossolo Háplico Eutrófico ocorre na região noroeste da área de pesquisa. O planossolo corresponde a solos minerais com horizonte B plânico, subjacente a qualquer tipo de horizonte A, podendo ou não apresentar horizonte E, álbico ou não (EMBRAPA, 2009).

Os planossolos são representados por solos minerais imperfeitamente ou mal drenados, com horizonte superficial ou subsuperficial eluvial, de textura mais leve, que contrasta abruptamente com o horizonte B imediatamente subjacente, adensado, geralmente de acentuada concentração de argila, permeabilidade lenta ou muito lenta, constituindo, por vezes, um horizonte endurecido ou cimentado quando seco, responsável pela formação de lençol d'água sobreposto (suspenso), de existência periódica e presença variável durante o ano (EMBRAPA, 2009).

O Luvissolo Crômico Órtico é encontrado ao sul da área de pesquisa ao longo do Rio Caxitoré. Os Luvissolos são solos minerais, não hidromórficos, com horizonte $B$ textural com argila de atividade alta e saturação por bases alta, imediatamente abaixo de horizonte A ou horizonte E (EMBRAPA, 2009).

Estes solos variam de bem a imperfeitamente drenados, sendo normalmente pouco profundos, com espessura do solum $(A+B$, exceto $B C) \leq 80 \mathrm{~cm}$., com sequência de horizontes $\mathrm{A}$, Bt e $\mathrm{C}$, e nítida diferenciação entre os horizontes $\mathrm{A}$ e Bt, devido ao contraste de textura, cor e/ou estrutura entre eles. A transição para o horizonte B textural é clara ou abrupta, e grande parte dos solos desta classe apresenta mudança textural abrupta. 
Podem ou não apresentar pedregosidade na parte superficial e o caráter solódico ou sódico, na parte subsuperficial (EMBRAPA, 2009).

Apresentam cores desde vermelhas a acinzentadas, horizonte $B$ textural ou nítico abaixo de horizonte A fraco, moderado ou horizonte $\mathrm{E}$, argila de atividade alta e alta saturação por bases. A mineralogia das argilas condiciona certo fendilhamento em alguns perfis nos períodos secos (IBGE, 2007).

As formações vegetais do Estado têm uma distribuição que obedece a uma zonalidade. As influências físicas sobre a vegetação se manifestam em função de fenômenos associados com a proximidade do mar, com a direção e o deslocamento dos ventos que dirigem as condições de pluviosidade da costa para as depressões sertanejas. E também, a própria conformação e/ou disposição do continente em relação aos deslocamentos dos ventos tendem a interferir, assim como as diferenças altimétricas. Nos Maciços pré-litorâneos, o relevo é condicionador de diminuições térmicas ou participa como efeito barreira. As diferenças litológicas e edáficas condicionam também as características dos meios fitogeográficos. No entanto, as atividades antrópicas agem no sentido de degradar a cobertura vegetal primária e os solos. Desta forma, modificam-se as condições dos meios fitoecológicos, afetando toda a ecodinâmica das paisagens (SOUZA, 2000).

A distribuição espacial das formações vegetais descritas e o uso da terra podem ser visualizados no mapa de cobertura e uso da terra, adaptado de Freires et al. (2019), na Figura 10.

Conforme o mapa fitoecológico do IPECE (2007), ocorrem as seguintes formações vegetais na área de pesquisa: Complexo vegetacional da zona litorânea (Tabuleiro), Caatinga arbustiva densa, Caatinga arbustiva aberta; Floresta subperenifólia tropical plúvionebular (matas úmidas, serranas) e Floresta subcaducifólia tropical pluvial (mata seca).

A vegetação de tabuleiro encontra-se bastante descaracterizada em relação á condições originais. É típica dos Glacis Pré-litorâneos da Formação Barreiras, deficientemente dissecados pela drenagem que demanda a costa (SOUZA 2000). Essa formação pode ser encontrada na porção nordeste da área de pesquisa sobre os tabuleiros pré-litorâneos, porém bastante alterada devido as práticas agrícolas. 
De acordo com Fernandes (1990 apud Souza, 2000), o conjunto vegetacional dos tabuleiros não se apresenta homogêneo, sobretudo quando é analisado por meio do quadro fisionômico. Considerando as plantas lenhosas, podem ser destacadas duas feições distintas: vegetação subperenifólia e vegetação caducifólia.

A vegetação subperenifólia tem, comumente, porte arbustivo e arbóreo/arbustivo e situa-se principalmente nas áreas próximas ao litoral recobrindo Argissolos Vermelho-amarelos e Neossolos quartzarênicos. À medida que os sedimentos da Formação Barreiras assumem menor espessura no contato com os solos das depressões sertanejas, passa a haver o predomínio de espécies caducifólias com as condições fisionômicas e florísticas que mais se aproximam das caatingas sertanejas (SOUZA, 2000).

De acordo com Rizzini (1997), Caatinga é o termo genérico que designa um complexo de vegetação decídua e xerófila formado por vegetais lenhosos e mais ou menos rico em cactáceas e bromeliáceas rígidas. Ora dominam os primeiros, ora as segundas, exibindo misturas em proporção muito variada, conforme a natureza do substrato e a secura do clima.

Conforme Souza (2000), as caatingas apresentam variados padrões fisionômicos e florísticos e tendem a prevalecer onde as condições dos sertões se estabelecem. Essa formação vegetal ocorre a partir do contato geológico entre os sedimentos da Formação Barreiras e as rochas do embasamento cristalino. Estendendo-se para o interior onde as deficiências hídricas se agudizam.

Segundo Fernandes (2003), a caatinga caracteriza-se por formações florísticas afilas, em regra, desenvolvidas sobre um patamar cristalino, configurando-se em duas fisionomias: uma arbórea (caatinga alta), outra arbustiva (caatinga baixa).

A caatinga apresenta um padrão fisionômico arbóreo apenas onde as condições semiáridas são mais moderadas e onde os solos têm melhores condições de fertilidade natural (SOUZA, 2000). De acordo com Fernandes (2006), a caatinga arbórea apresentase em três estratos: um arbóreo, com representantes de 8-12 m de altura, outro arbustivo/sub-arbustivo com indivíduos de 2-5 m e um herbáceo que apresenta um caráter anual ou efêmero, sendo pobre em espécies. 
Figura 10 - Mapa de cobertura e uso da terra

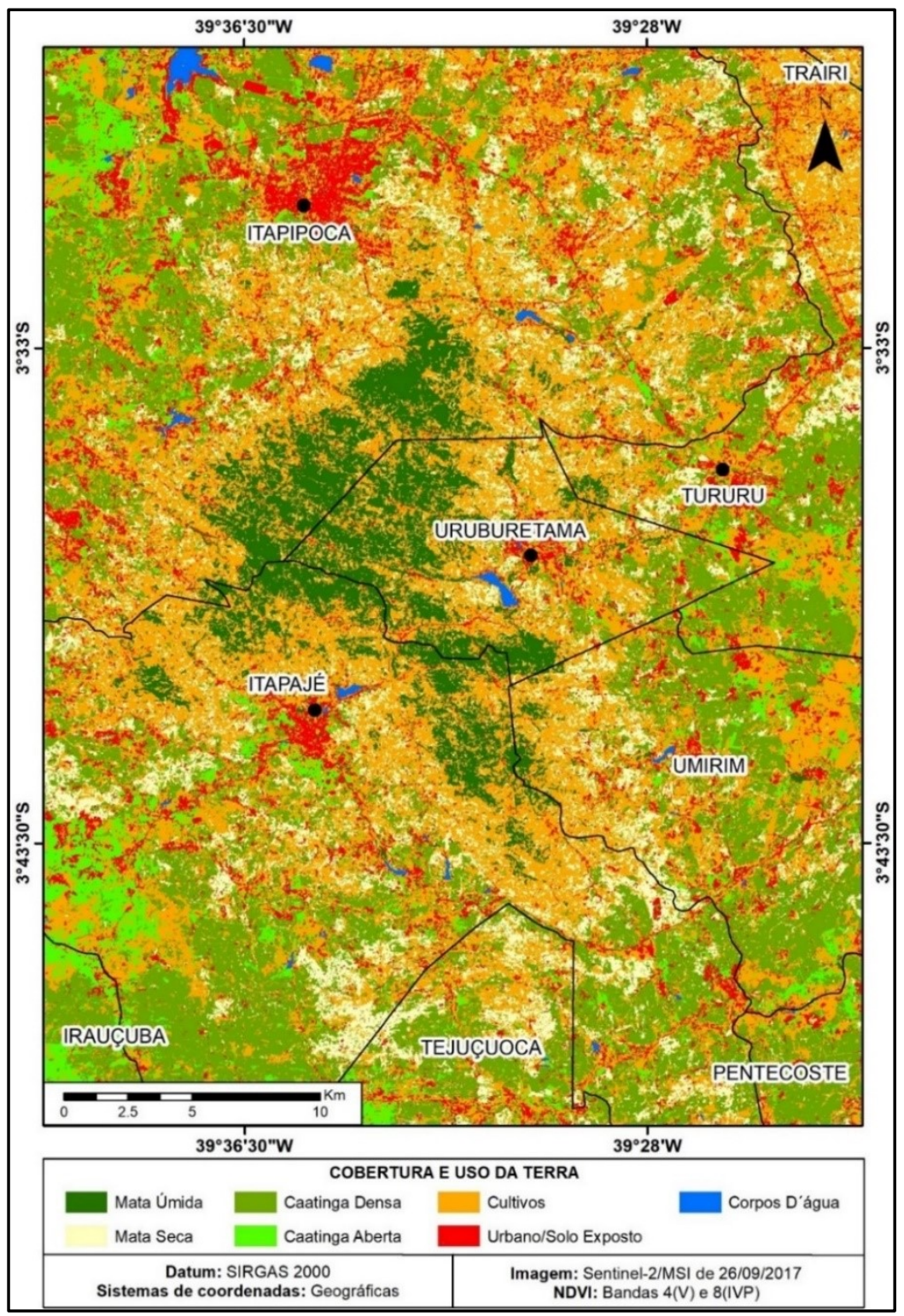

Fonte: Adaptado de Freires et al.(2019).

À medida que as condições ambientais se tornam mais limitativas, as caatingas assumem um padrão fisionômico de caatinga arbustiva densa ou caatinga arbustiva aberta. A caatinga arbustiva densa ao ser degradada, passa a ter o aspecto de caatinga arbustiva aberta (SOUZA, 2000).

De acordo com Fernandes (2006), a caatinga arbustiva compõe-se de um estrato com indivíduos de 3-5 m de altura, com raros exemplares arbóreos; e outro de porte mais reduzido de natureza herbáceo, com componentes naturais de curta duração ou efêmeros. 
A caatinga arbustiva densa desenvolve-se sobre solos arenosos com pouca profundidade, enquanto a caatinga arbustiva aberta recobre solos rasos e duros, comumente encharcados durante o período chuvoso (FERNANDES, 2006).

Essas formações ocorrem nas áreas pediplanada da depressão sertaneja, no entorno do Maciço de Uruburetama. A caatinga arbustiva densa pode ser observada, predominantemente, no setor Norte/Leste, enquanto a caatinga arbustiva aberta é encontrada sobretudo no setor Sul/Oeste do maciço.

A floresta subperenifólia tropical plúvionebular (mata úmida) ocorre na vertente de barlavento e platôs da Serra de Uruburetama. Conforme Souza (2000), essa unidade fitoecológica comumente se desenvolve a partir da cota de $600 \mathrm{~m}$ e possui caráter preponderantemente perenifólio. As espécies de porte arbóreo podem atingir até 20 metros. A ocorrência de estrato arbustivo de menor porte não chega a ser genérico. Nesse conjunto vegetacional, pode ser observado uma grande abundância de líquens, epífitas e lianas.

Na serra pode ser encontrada ainda a Floresta subcaducifólia tropical pluvial (mata seca). Essa formação está localizada a retaguarda da mata úmida, em cotas altimétricas inferiores que apresentam menor disponibilidade hídrica. É uma vegetação cuja fisionomia é alterada conforme a distribuição pluviométrica sazonal, podendo ser encontrada também em relevos cristalinos de menor porte, como os inselbergs.

Tanto a mata úmida como a mata seca se encontram em elevado estágio de degradação, sobretudo, devido as práticas agrícolas, desprovidas de técnicas adequadas de cultivo; e ao fato de introduzirem culturas incompatíveis as características edafoclimáticas do local, como é caso da bananeira.

\subsection{Aspectos socioambientais}

Conforme estimativa do IBGE (2018), os municípios que compõem a área de estudo apresentam uma população de 373.788 habitantes (Tabela 1). O Município 
de Itapipoca, que ocupa maior extensão da área de estudo, é o único com população superior a 100 mil habitantes. O Município de Uruburetama, por sua vez, com uma população modesta de 21.725 habitantes, apresenta-se totalmente inserido na área de pesquisa.

Essa População se distribui de forma equilibrada entre a área urbana e a área rural. Conforme pode ser observado na Tabela 7, 192.823 habitantes residem no perímetro urbano, enquanto 150.540 se distribuem no meio rural. Contudo, apenas três municípios apresentam população predominantemente rural, que são: Tejuçuoca, Trairi e Tururu.

Tabela 1 - População estimada dos municípios que compõem a área de estudo

\begin{tabular}{l|c|c|c|c|c|c}
\hline Municípios & $\begin{array}{c}\text { População estimada } \\
\text { para 2018 }\end{array}$ & $\begin{array}{c}\text { População } \\
\text { Urbana }\end{array}$ & $\mathbf{( \% )}$ & $\begin{array}{c}\text { População } \\
\text { Rural }\end{array}$ & (\%) & hab./Km \\
\hline Irauçuba & 24.003 & 14.343 & 64,2 & 7.981 & 35,8 & 15,28 \\
Itapajé & 52.240 & 33.990 & 70,3 & 14.360 & 29,7 & 110,01 \\
Itapipoca & 128.135 & 66.909 & 57,6 & 49.156 & 42,4 & 71,90 \\
Pentecoste & 37.326 & 21.394 & 60,4 & 14.006 & 39,6 & 25,68 \\
Tejuçuoca & 18.998 & 6.335 & 37,7 & 10.492 & 62,3 & 22,42 \\
Trairi & 55.535 & 18.784 & 36,5 & 32.638 & 63,5 & 55,55 \\
Tururu & 16.015 & 5.288 & 36,7 & 9.120 & 63,3 & 71,23 \\
Umirim & 19.811 & 11.091 & 59,0 & 7.711 & 41,0 & 59,35 \\
Uruburetama & 21.725 & 14.689 & 74,3 & 5.076 & 25,7 & 203,61 \\
Total & 373.788 & 192.823 & --- & 150.540 & --- & --- \\
\hline
\end{tabular}

Fonte: IBGE (2018)

Os municípios com os maiores percentuais de população urbana são: Itapipoca (57,6\%), Umirim (59,35\%), Pentecoste $(60,4 \%)$, Irauçuba (64,2\%), Itapajé $(70,3 \%)$ e Uruburetama (74,30\%). Com exceção de Irauçuba e Pentecoste, os demais municípios estão inseridos parcialmente na vertente úmida do Maciço de Uruburetama. Fato que remete a pressão exercida por essa população sobre os recursos locais, a partir das diversas intervenções realizadas. A expansão urbana desordenada que vem 
ocorrendo nessa área tem promovido alterações significativas na paisagem ao longo do tempo.

Verifica-se que as maiores densidades demográficas ocorrem justamente nos municípios que englobam a vertente úmida do Maciço de Uruburetama: Umirim $(59,35)$, Tururu $(71,23)$, Itapipoca $(71,90)$, Itapajé $(110,01)$ e Uruburetama $(203,61)$. A maior oferta de água e a ocorrência de solos mais desenvolvidos favoreceu a ocupação dessa área.

O crescimento urbano ocorrido ao longo dos anos nesses municípios se deu sem planejamento e não há o devido monitoramento da expansão da malha urbana no maciço. É possível observar ocupações em áreas de preservação permanentes, com mais $45^{\circ}$ de declividade, e habitações em setores sob risco geológicos a movimentos gravitacionais, como ilustrado na Figura 11. As habitações são erguidas em áreas instabilizadas pelo plantio de bananeiras (A) ou em rotas de colisão de blocos (B) que muitas vezes despencam encosta abaixo.

Figura 11 - Casas construídas em áreas de preservação permanente e sob risco geológico. (A) Uruburetama; (B) Itapajé

(A)

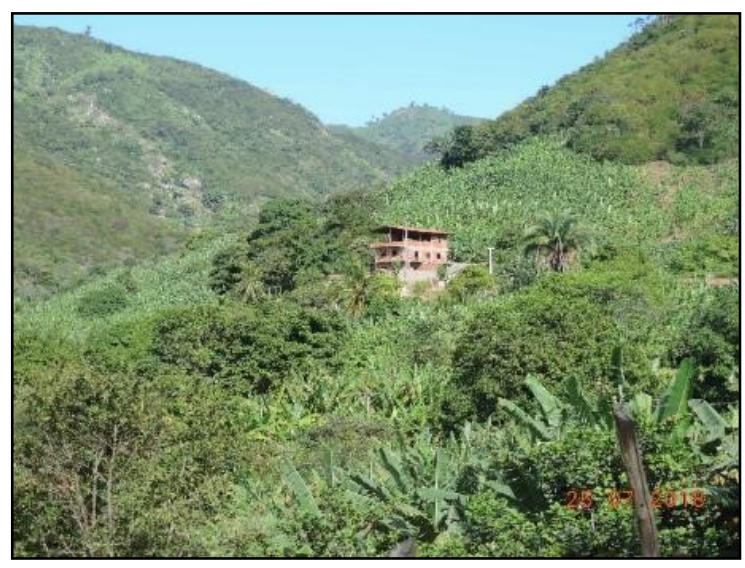

(B)

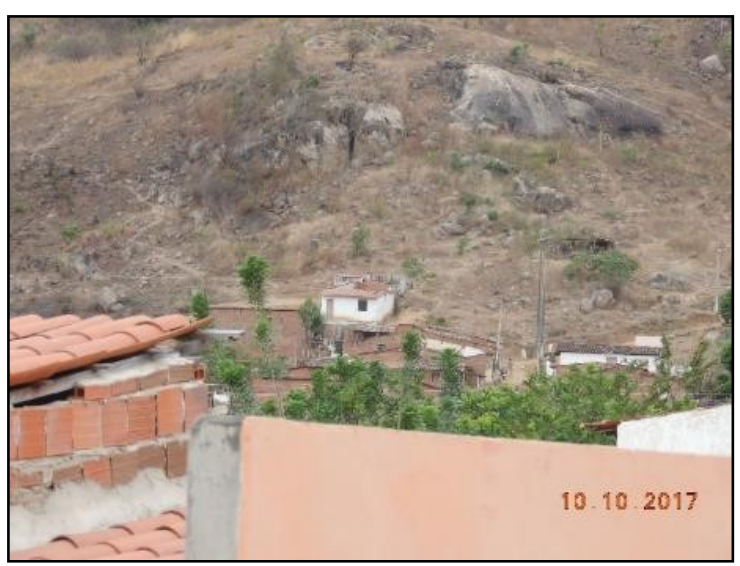

Fotos: Eduardo Freires (A - 25/07/2018, B - 10/10/2017)

Uma prática comum no maciço são os cortes em taludes para construção de habitações ou para ampliação de áreas edificáveis (Figura 12-A.). Na Figura 12-B pode ser observada a área de corte ocupada por um balneário. 
Figura 12 - (A) Recorte de talude para edificação; (B) Balneário construído na área localidade de Santa Maria - Uruburetama

(A)

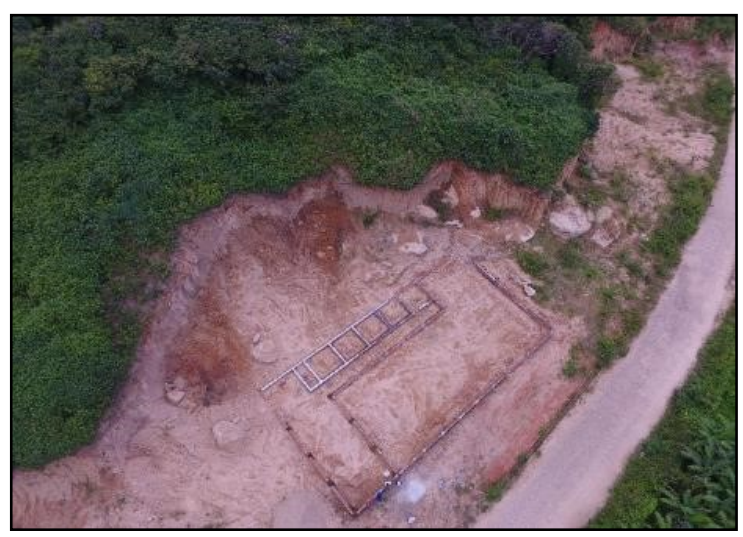

(B)

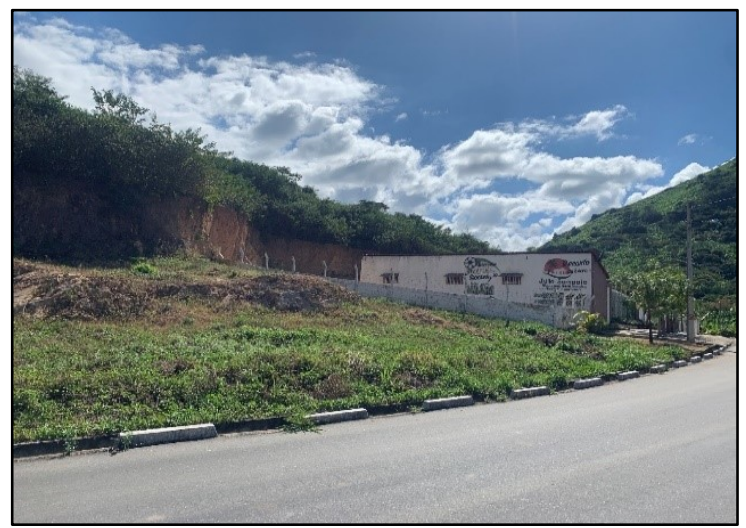

Fotos: Daniel Dantas (obtida por ARP, 20/05/2017); Eduardo Freires (03/07/2020)

É possível observar ainda que muitas vezes as encostas são cortadas para exploração do arisco (Figura 13), material arenoso utilizado para produção de argamassa, junto com cimento, e destinado a construção civil para obras de alvenaria.

Figura 13 - Exploração de arisco no município de Itapipoca

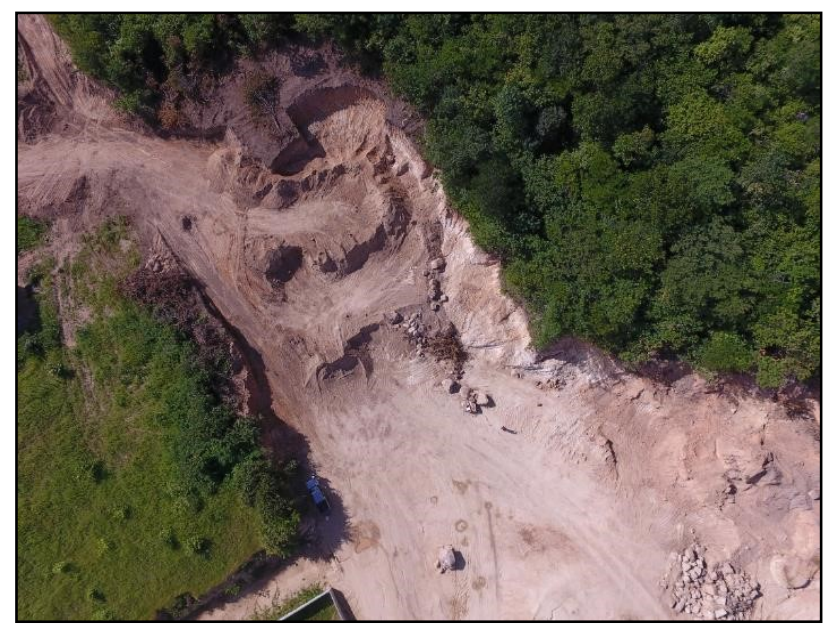

Foto: Daniel Dantas (obtida por ARP, 21/05/2017)

A necessidade de interligar as diversas localidades entre si, e aos centros urbanos, induziu a abertura de estradas, que em sua grande maioria foram edificadas sem os devidos cuidados de engenharia para estabilizar os taludes. Como consequência é comum observar movimentos de massa ao longo dessas 
estradas (A), potencializados pelas atividades agrícolas que são praticadas de forma inadequada, como pode ser observado na Figura 14. Esse fato demonstra que o próprio poder público contribui decisivamente para agravar o quadro de degradação do maciço. As estradas feitas para integrar, muitas vezes, acabam por isolar as comunidades, que ficam sem acesso de transporte até que o material movimentado seja retirado. O que pode demorar semanas, dependendo do volume e material movimentado, dos recursos disponíveis e da acessibilidade das máquinas.

Figura 14 - Movimentos de massa - (A) Queda de bloco em estrada em São Jerônimo/Itapipoca; (B) Escorregamento rotacional em talude de estrada e área cultivada na localidade de Itacolomy, em Uruburetama

(A)

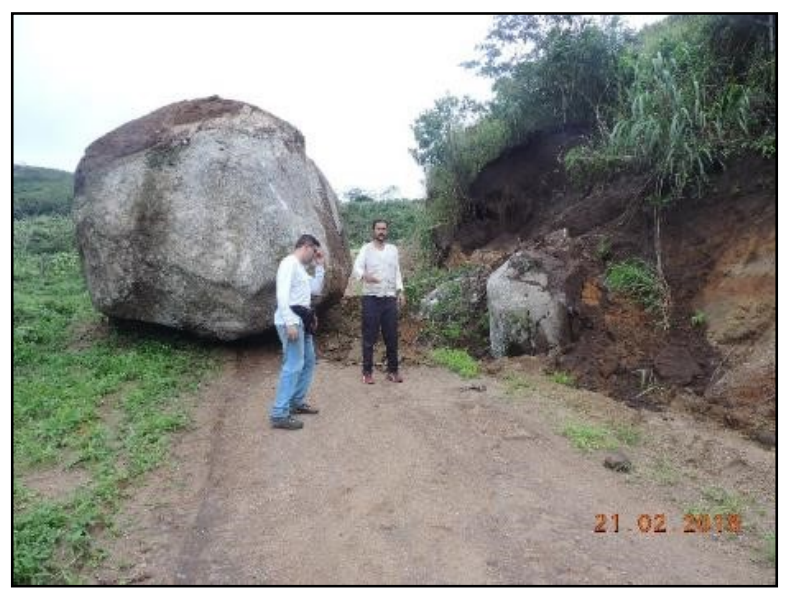

(B)

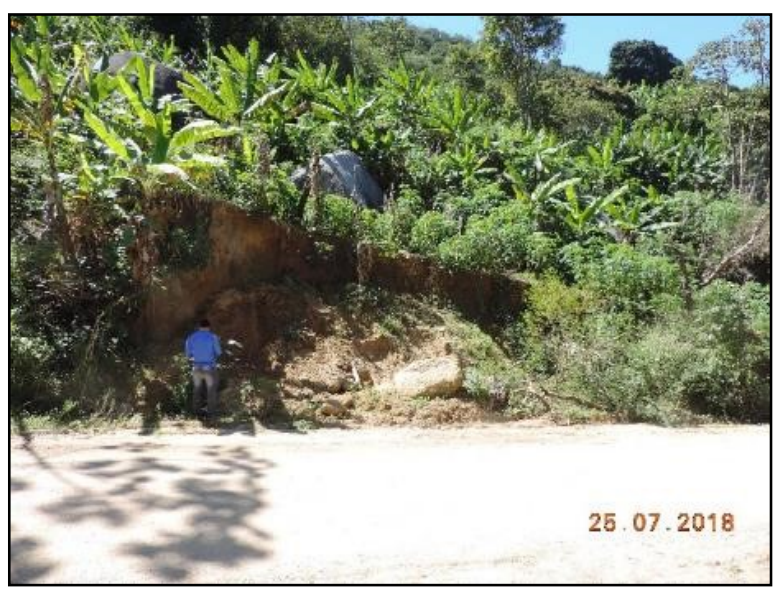

Fotos: Eduardo Freires e Cláudio Ângelo (A - 21/02/2018, B - 25/07/2018)

Os cortes de estradas realizados pelo poder público municipal e estadual, através de retroescavadeiras, intensificam os processos erosivos e consequentemente favorecem os movimentos de massa, uma vez que durante o corte são produzidos sulcos verticais na superfície dos taludes que canalizam o fluxo dágua durante as chuvas, tornando-o concentrado, o que acarreta na formação de ravinas, como pode se observar na Figura 15.

Todos os municípios da área de estudo que estão na abrangência do Maciço de Uruburetama dispõem de órgão gestor de meio ambiente (Quadro 1). Todavia, observase que a maioria dos municípios não adotou medidas legais ou técnicas para evitar 
desastres decorrentes de escorregamentos ou deslizamentos. Apenas Irauçuba e Itapipoca dispõem de Lei de Uso e Ocupação e Plano Diretor, respectivamente, que contemple a prevenção de escorregamento ou deslizamentos de encostas. Todos os municípios não dispõem de carta geotécnica de aptidão a urbanização ou cadastro de risco. Apenas o município de Uruburetama alega possuir mecanismos de controle e fiscalização para evitar ocupação em áreas susceptíveis a desastres, embora as atividades de campo demonstrem o contrário.

Figura 15 - Estrada na localidade de Itacoatiara - Itapipoca

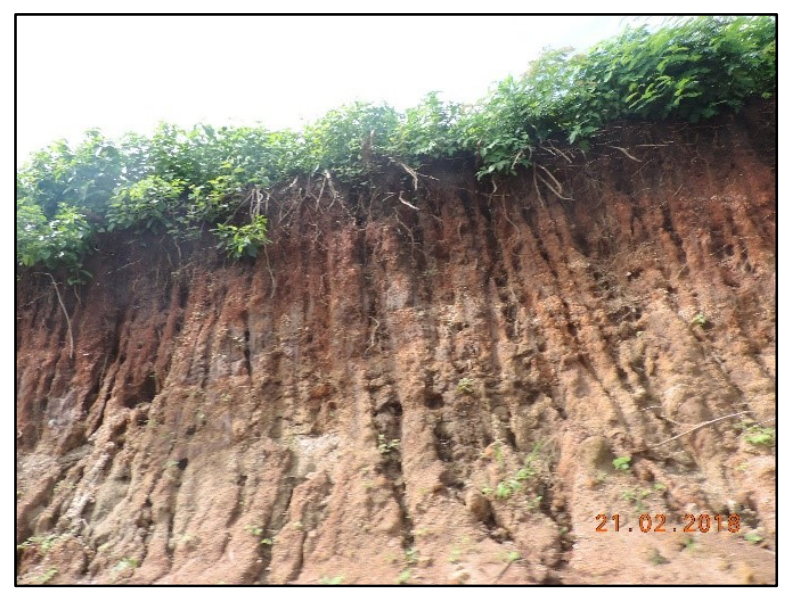

Foto: Eduardo Freires (21/02/2018)

Quadro 1 - Gerenciamento de riscos de desastres nos municípios do Maciço de Uruburetama

\begin{tabular}{|c|c|c|c|c|c|c|}
\hline \multirow[b]{2}{*}{ Município } & \multicolumn{6}{|c|}{$\begin{array}{c}\text { Gerenciamento de Riscos de desastres decorrentes de escorregamento ou } \\
\text { deslizamento }\end{array}$} \\
\hline & $\begin{array}{l}\text { Órgão } \\
\text { Gestor } \\
\text { de Meio } \\
\text { ambiente }\end{array}$ & $\begin{array}{l}\text { Lei de Uso e } \\
\text { Ocupação }\end{array}$ & $\begin{array}{l}\text { Plano } \\
\text { Diretor }\end{array}$ & $\begin{array}{c}\text { Carta } \\
\text { geotécnica } \\
\text { de aptidão a } \\
\text { urbanização }\end{array}$ & $\begin{array}{l}\text { Cadastro } \\
\text { de risco }\end{array}$ & $\begin{array}{c}\text { Mecanismos } \\
\text { de controle e } \\
\text { fiscalização para } \\
\text { evitar ocupação em } \\
\text { áreas susceptíveis a } \\
\text { desastres }\end{array}$ \\
\hline Irauçuba & SIM & SIM & NÃO & NÃO & NÃO & NÃO \\
\hline Itapajé & SIM & NÃO & NÃO & NÃO & NÃO & NÃO \\
\hline Itapipoca & SIM & NÃO & SIM & NÃO & NÃO & NÃO \\
\hline Tejuçuoca & SIM & NÃO & NÃO & NÃO & NÃO & NÃO \\
\hline Tururu & SIM & NÃO & NÃO & NÃO & NÃO & NÃO \\
\hline Umirim & SIM & NÃO & NÃO & NÃO & NÃO & NÃO \\
\hline Uruburetama & SIM & NÃO & NÃO & NÃO & NÃO & SIM \\
\hline
\end{tabular}

Fonte: IBGE (2018) 
Chama atenção o fato de no último levantamento de registro de escorregamento ou deslizamento, num período de 4 anos (2013 a 2017), o único município a apresentar ocorrência foi Itapajé, como verificado no Quadro 2.

Quadro 2 - Registros de ocorrências de escorregamentos nos municípios da área de estudo

\begin{tabular}{|c|c|c|c|c|c|c|c|}
\hline \multirow[b]{2}{*}{ Município } & \multicolumn{7}{|c|}{ Escorregamento ou deslizamento de encosta entre 2013 e 2017} \\
\hline & Ocorrência & $\begin{array}{l}\text { Taludes e } \\
\text { encostas } \\
\text { sujeitas a } \\
\text { deslizamentos }\end{array}$ & \begin{tabular}{|l|} 
Áreas \\
urbanas \\
com \\
processos \\
erosivos \\
crônicos \\
\end{tabular} & $\begin{array}{l}\text { Sem } \\
\text { infraestrutura } \\
\text { de drenagem }\end{array}$ & $\begin{array}{l}\text { Com } \\
\text { ocupações } \\
\text { regulares }\end{array}$ & $\begin{array}{l}\text { Com } \\
\text { ocupações } \\
\text { irregulares }\end{array}$ & $\begin{array}{l}\text { Sem } \\
\text { ocupação }\end{array}$ \\
\hline Irauçuba & NÃO & --- & --- & --- & --- & --- & --- \\
\hline Itapajé & SIM & SIM & SIM & NÃO & NÃO & SIM & NÃO \\
\hline Itapipoca & NÃO & --- & --- & --- & --- & --- & --- \\
\hline Pentecoste & NÃO & --- & --- & --- & --- & --- & --- \\
\hline Tejuçuoca & NÃO & --- & --- & --- & --- & --- & --- \\
\hline Trairi & NÃO & --- & --- & --- & --- & --- & --- \\
\hline Tururu & NÃO & --- & --- & --- & --- & --- & --- \\
\hline Umirim & NÃO & --- & --- & --- & --- & --- & --- \\
\hline Uruburetama & NÃO & --- & --- & --- & --- & --- & --- \\
\hline
\end{tabular}

Fonte: IBGE (2018)

Constata-se, a partir do exposto, que embora todos os municípios possuam órgãos ambientais gestores, estes não dispõem de recursos financeiros, humanos e técnicos que possam garantir o planejamento e a fiscalização do uso e ocupação da terra. A maioria desses órgãos de meio ambiente atuam integrados a outros setores da administração, como agropecuária, recursos hídricos, turismo e cultura. Muitas vezes as suas atuações esbarram em interesses conflitantes, tornando mais difíceis as tomadas de decisões. É comum os interesses políticos e econômicos prevalecerem sobre as questões ambientais e sociais.

Assim como a expansão urbana, a atividade agrícola é um dos principais agentes responsáveis pela alteração da paisagem e consequentemente pela degradação dos solos no Maciço de Uruburetama. Embora essa atividade econômica, juntamente com a pecuária, seja a terceira em contribuição para o Produto Interno Bruto (PIB) da maioria 
dos municípios analisados (Gráfico 1), é a que exige maior disponibilidade de terras, sendo responsável pela supressão da vegetação nativa e de todos problemas derivados de práticas inadequadas.

Como pode ser observado na Tabela 2, de 2007 a 2017, a produção agrícola das principais culturas permanentes que são cultivadas na área de pesquisa apresentou declínio. Apesar da queda da produção agrícola, as áreas destinadas aos cultivos praticamente permaneceram as mesmas, apresentando uma pequena variação negativa, como verificado na Tabela 3.

Gráfico 1 - participação dos setores da atividade econômica no Produto Interno Bruto dos Municípios

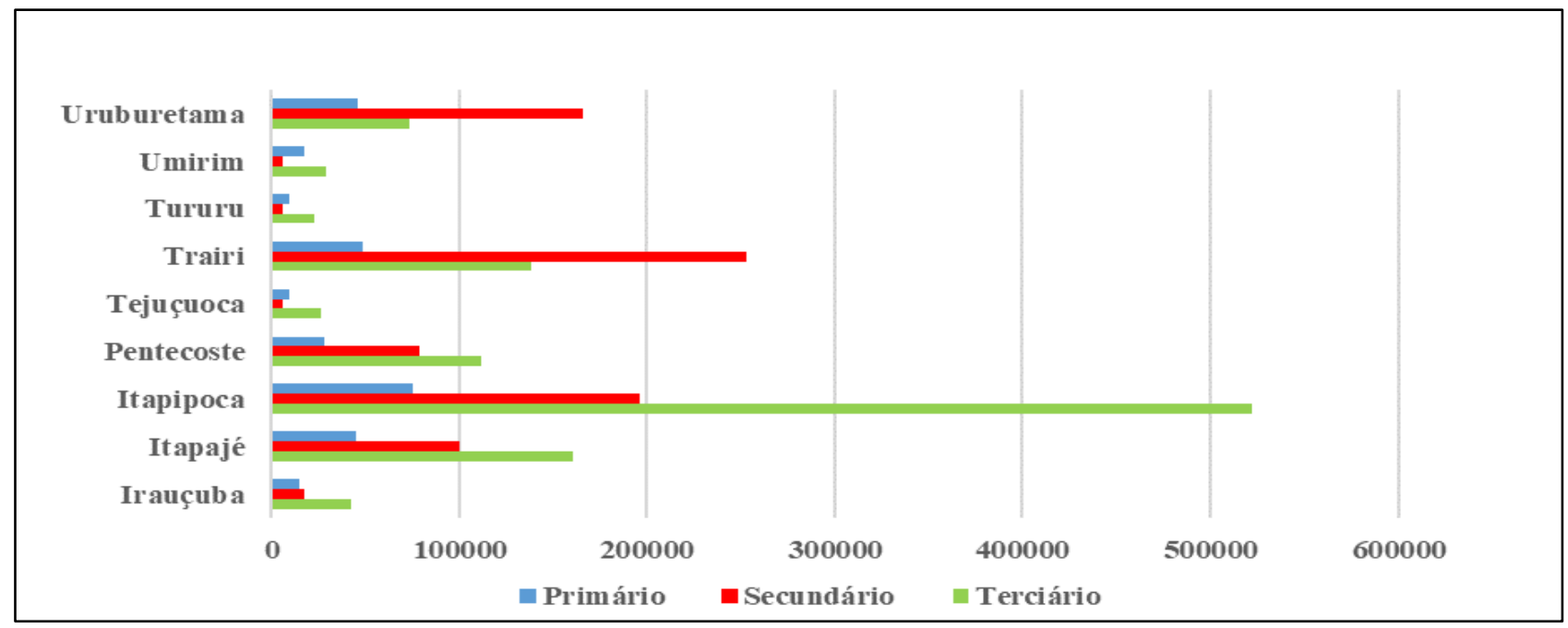

Fonte: IBGE (2018)

Tabela 2 - Produção agrícola de culturas permanentes nos municípios que compõem a vertente úmida do Maciço de Uruburetama nos anos de 2007 e 2017

\begin{tabular}{l|c|c|c|c|c|c|c|c}
\hline \multirow{2}{*}{ Município } & \multicolumn{8}{c}{ Lavoura Permanente (produção em t) } \\
\cline { 2 - 10 } & \multicolumn{2}{|c}{ Banana } & \multicolumn{2}{c}{ Castanha de Caju } & \multicolumn{2}{c}{ Mamão } & \multicolumn{2}{c}{ Manga } \\
\cline { 2 - 10 } & $\mathbf{2 0 0 7}$ & $\mathbf{2 0 1 7}$ & $\mathbf{2 0 0 7}$ & $\mathbf{2 0 1 7}$ & $\mathbf{2 0 0 7}$ & $\mathbf{2 0 1 7}$ & $\mathbf{2 0 0 7}$ & $\mathbf{2 0 1 7}$ \\
\hline Irauçuba & 128 & 5 & 1 & 1 & -- & 46 & 53 & 14 \\
Itapajé & 20.000 & 13.194 & 76 & 66 & 90 & 134 & 417 & 208 \\
Itapipoca & 21.433 & 17.062 & 15.342 & 4.131 & 1.564 & --- & 553 & 653 \\
Pentecoste & 1.200 & 62 & 80 & 21 & 570 & 611 & 50 & 47 \\
Tejuçuoca & 18 & 10 & 7 & 8 & --- & 113 & 15 & 4 \\
Trairi & 658 & 497 & 672 & 4.341 & --- & --- & 109 & 96 \\
\hline & \multicolumn{8}{c}{} \\
\hline
\end{tabular}




\begin{tabular}{l|c|c|c|c|c|c|c|c|}
\hline \multirow{2}{*}{ M...Conclusão } & \multicolumn{10}{c|}{ Lavoura Permanente (produção em t) } \\
\cline { 2 - 10 } & \multicolumn{2}{|c|}{ Banana } & \multicolumn{2}{c|}{ Castanha de Caju } & \multicolumn{2}{c|}{ Mamão } & \multicolumn{2}{c|}{ Manga } \\
\cline { 2 - 9 } & $\mathbf{2 0 0 7}$ & $\mathbf{2 0 1 7}$ & $\mathbf{2 0 0 7}$ & $\mathbf{2 0 1 7}$ & $\mathbf{2 0 0 7}$ & $\mathbf{2 0 1 7}$ & $\mathbf{2 0 0 7}$ & $\mathbf{2 0 1 7}$ \\
\hline Tururu & 239 & 83 & 134 & 693 & -- & --- & 71 & 200 \\
Umirim & 738 & 646 & 47 & 73 & 912 & 342 & 85 & 77 \\
Uruburetama & 26.435 & 29.568 & 45 & 147 & 132 & 268 & 860 & 866 \\
Total & $\mathbf{6 9 . 6 7 0}$ & $\mathbf{6 1 . 1 2 7}$ & $\mathbf{1 6 . 4 0 4}$ & $\mathbf{9 . 4 8 1}$ & $\mathbf{3 . 2 6 8}$ & $\mathbf{1 . 5 1 4}$ & $\mathbf{2 . 2 1 3}$ & $\mathbf{2 . 1 6 5}$ \\
\hline
\end{tabular}

Fonte: IBGE (2018)

Tabela 3 - Área plantada de culturas permanentes nos municípios que compõem a vertente úmida do Maciço de Uruburetama nos anos de 2007 e 2017

\begin{tabular}{l|c|c|c|c|c|c|c|c}
\hline \multirow{2}{*}{ Município } & \multicolumn{9}{|c}{ Lavoura Permanente (área destinada ao cultivo em ha) } \\
\cline { 2 - 10 } & \multicolumn{2}{|c}{ Banana } & \multicolumn{2}{c}{ Castanha de Caju } & \multicolumn{2}{c}{ Mamão } & \multicolumn{2}{c}{ Manga } \\
\cline { 2 - 10 } & $\mathbf{2 0 0 7}$ & $\mathbf{2 0 1 7}$ & $\mathbf{2 0 0 7}$ & $\mathbf{2 0 1 7}$ & $\mathbf{2 0 0 7}$ & $\mathbf{2 0 1 7}$ & $\mathbf{2 0 0 7}$ & $\mathbf{2 0 1 7}$ \\
\hline Irauçuba & 17 & 3 & 15 & 15 & --- & 3 & 5 & 2 \\
Itapajé & 5.000 & 4.712 & 630 & 619 & 3 & 5 & 30 & 26 \\
Itapipoca & 3.244 & 2.752 & 15.542 & 15.935 & 17 & -- & 110 & 114 \\
Pentecoste & 120 & 15 & 983 & 170 & 15 & 15 & 3 & 5 \\
Tejuçuoca & 2 & 5 & 67 & 30 & --- & 3 & 1 & 1 \\
Trairi & 82 & 72 & 11.382 & 11.882 & --- & --- & 16 & 16 \\
Tururu & 34 & 15 & 3.108 & 3.012 & --- & -- & 10 & 25 \\
Umirim & 82 & 110 & 380 & 376 & 25 & 10 & 9 & 8 \\
Uruburetama & 3.110 & 3.200 & 356 & 352 & 3 & 6 & 86 & 75 \\
Total & $\mathbf{1 1 . 6 9 1}$ & $\mathbf{1 0 . 8 8 4}$ & $\mathbf{3 2 . 4 6 3}$ & $\mathbf{3 2 . 3 9 1}$ & $\mathbf{6 3}$ & $\mathbf{4 2}$ & $\mathbf{2 7 0}$ & $\mathbf{2 7 2}$ \\
\hline
\end{tabular}

Fonte: IBGE (2018)

Como pode ser observado, houve uma redução de 8.523 toneladas de Banana, enquanto a área destinada ao cultivo declinou de 11.691 para 10.884 hectares (ha).

A ampliação da produção da banana foi verificada apenas no município de Uruburetama. Houve o crescimento da produção, que passou de 26.435 para 29.568 toneladas, ou seja, um incremento de 3.133 toneladas. Da mesma forma foi verificada a ampliação da área destinada ao cultivo dessa cultura, passando de 3.110 para 3.200 ha, um aumento de 90 ha.

Os demais municípios, apesar de apresentarem quedas na colheita, mantiveram grandes extensões de terras destinadas a esse cultivo. Sem falar nas lavouras abandonadas que não foram contabilizadas.

A bananicultura é a principal atividade agrícola desenvolvida na vertente úmida do Maciço de Uruburetama. Os maiores índices pluviométricos e a maior 
oferta de água para irrigação favorecem o cultivo dessa cultura na área. Em determinados setores da Serra a vegetação nativa foi completamente suprimida para o seu plantio como pode ser observado na Figura 16 - A.

Essa cultura é completamente inadequada para as características ambientais do maciço. Ao substituir a vegetação natural pela bananeira grandes extensões de solos são expostas aos agentes erosivos. Associa-se a isso o fato dessa planta apresentar raízes rasas que não garantem a estabilidade dos solos e quando cultivada em áreas íngremes, com grandes pluviometrias ou com um sistema de irrigação inadequado, tendem a desencadear movimentos de massa, que podem ser observadas com bastante frequência na vertente úmida do maciço, como verificado na Figura 16-B.

Figura 16 - (A)Plantio de banana em encosta, Santa Maria/Uruburetama; (B) Escorregamento rotacional associados a bananicultura, localidade de Itacolomy/Uruburetama

(A)

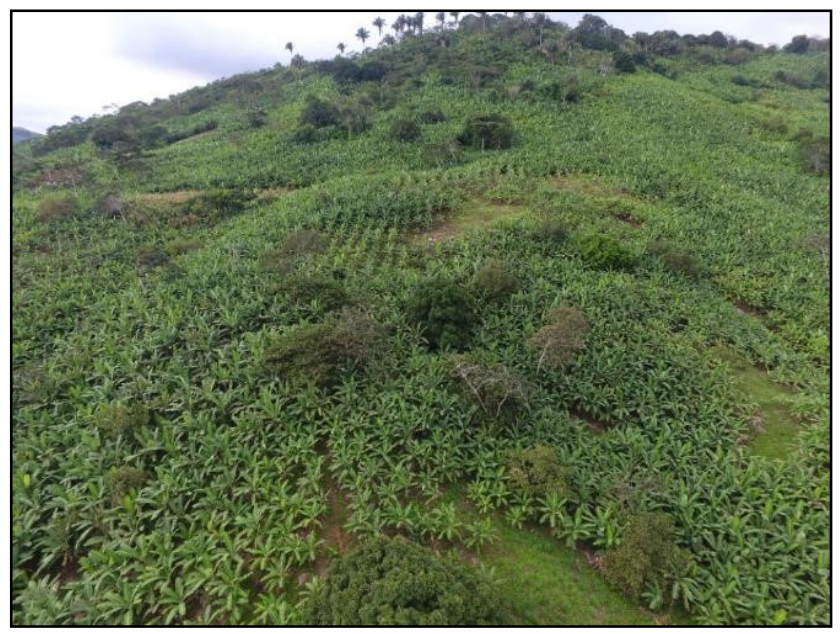

(B)

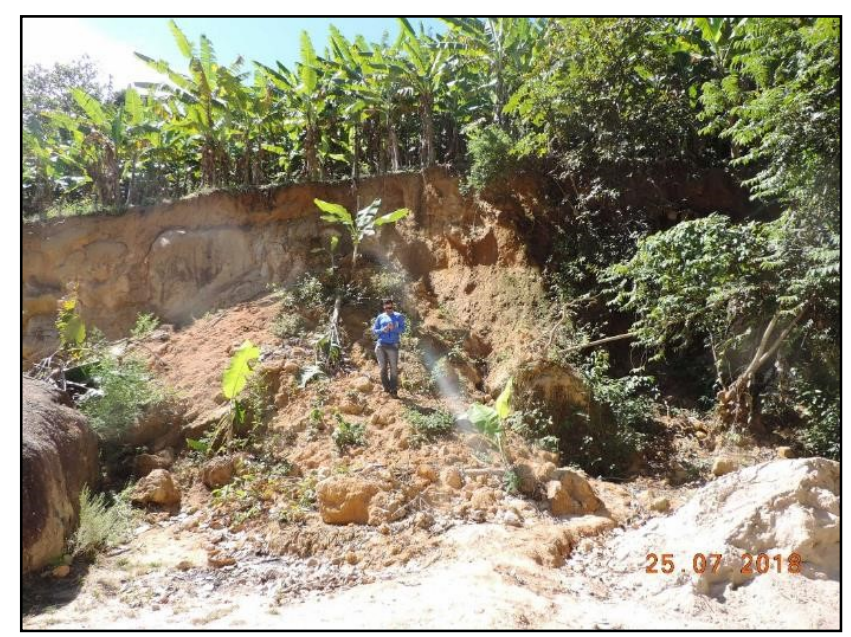

Foto: Daniel Gomes (obtida por ARP, 20/05/2017); Cláudio Ângelo (25/07/2018)

A falta de acompanhamento técnico e de fiscalização dessa atividade contribui para aumentar a ocorrência desses eventos. É comum ocorrer o plantio em encostas com declividade superior a $45^{\circ}$ ou em topos de serras com alturas superiores a 100 metros e com inclinação média superior a $25^{\circ}$, desrespeitando as 
determinações da Lei Federal n 12.651/2012 (Código Florestal Brasileiro) que visa, entre outros objetivos, preservar as paisagens, a estabilidade geológica e proteger o solo.

Os sistemas de irrigação também comprometem os solos, seja pelo excesso de água utilizado ou pelo rompimento das tubulações. O encharcamento do solo provocado por grande volume de água reduz a estabilidade da encosta, ao aumentar a carga, e contribui para o desencadeamento de movimentos gravitacionais. É comum observar na área de pesquisa movimento de massa associado à irrigação, como pode se observar na Figura 17.

Figura 17 - Escorregamento rotacional (A) associado à irrigação (B), Itacoatiara - Itapipoca

(A)

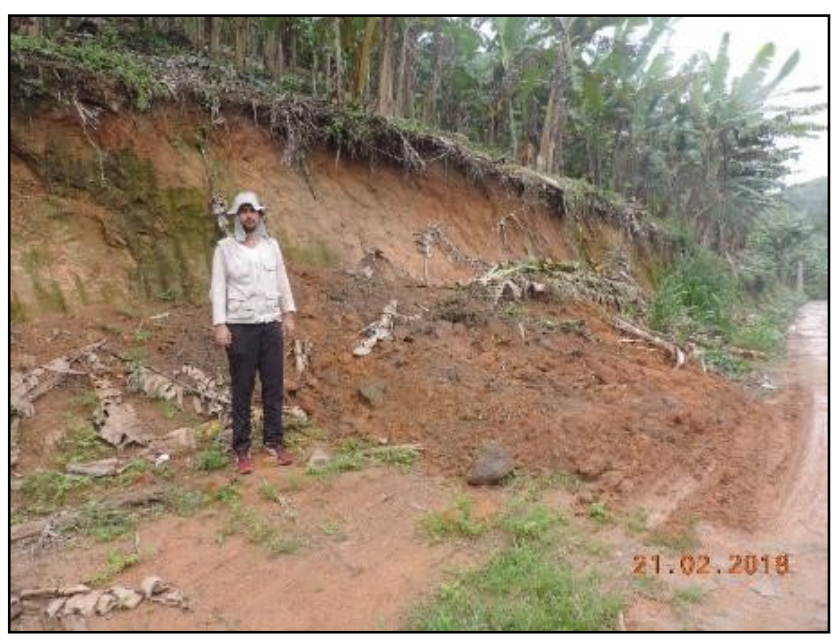

(B)

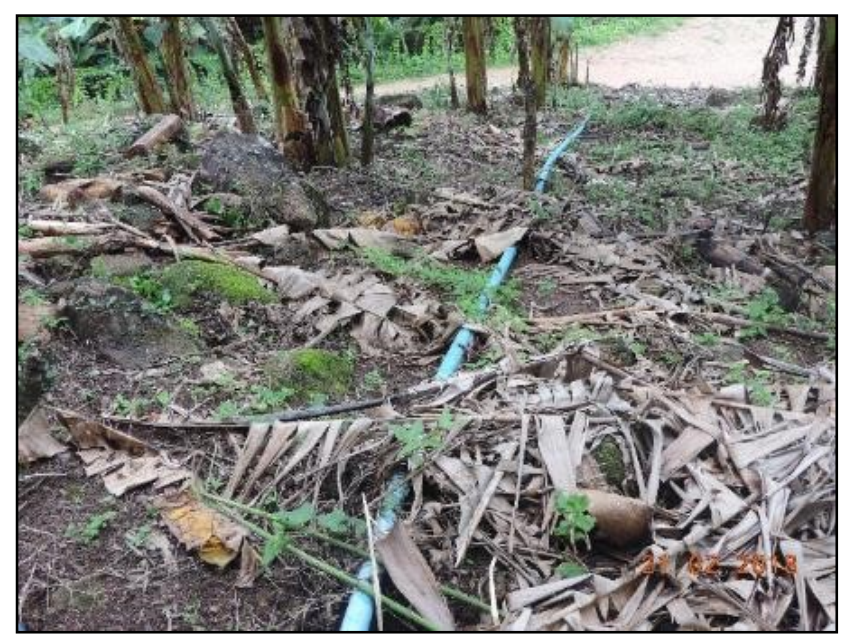

Fotos: Eduardo Freires (21/02/2018)

No caso da castanha de caju houve uma queda da produção de 6.923 toneladas, enquanto a área destinada ao seu cultivo apresentou uma leve redução, passando de 32.463 para 32.391 ha.

A produção da castanha de caju no período analisado aumentou em cinco municípios: Tejuçuoca, Trairi, Tururu, Umirim e Uruburetama. O crescimento mais expressivo ocorreu em Trairi, tendo a colheita passado de 672t para 4.341t, um incremento de mais de seis vezes e com uma pequena ampliação da área plantada. Por se tratar de um município litorâneo, Trairi apresenta características naturais que 
favorecem o cultivo da castanha de caju: solos profundos, desenvolvidos sobre Tabuleiros Pré-litorâneos, e altos índices pluviométricos.

Um fato que chama a atenção na produção da castanha de caju é o tamanho da área destinada ao seu cultivo. Obter produções expressivas significa destinar grandes extensões de terra para o plantio. Por isso a cajucultura contribui decisivamente para o quadro de degradação verificado na área de estudo, seja pela retirada da cobertura vegetal nativa e exposição do solo aos processos erosivos (Figura 18), ou pelos cultivos em áreas protegidas pela legislação, como encostas com mais de $45^{\circ}$ de declividade ou em várzeas de rios.

A produção de mamão no período despencou em mais de $46 \%$, passando de 3.268t para 1.514t. a área destinada ao cultivo por sua vez foi reduzida de 63 para 42 ha.

Com relação ao cultivo do mamão, diferente das demais culturas, não houve registro de produção em alguns municípios, como no caso de Trairi e Tururu. Além disso, em Irauçuba e Tejuçuoca só houve registro de produção no ano de 2017, tendo alcançado 46t e 113t respectivamente. Por outro lado, em Itapipoca só houve registro para o ano de 2007, tendo o município gerado uma produção de 1.564 t. O município de Umirim apresentou uma queda de produção no período, passando de $912 \mathrm{t}$ para $342 \mathrm{t}$.

Em Itapajé a produção cresceu de 90t em 2007 para 134t em 2017. Em pentecoste a produção passou de 570t em 2007 para 611t em 2017. A área destinada ao cultivo variou conforme a evolução da produção em ambos os municípios.

Em Uruburetama a produção de mamão mais que dobrou, passando de $132 \mathrm{t}$ em 2007 para 268t em 2017. A ampliação da área cultivada seguiu essa mesma tendência, subindo de 3 para 6 ha.

Figura 18 - Solo exposto em área de cultivo de caju no município de Itapajé 


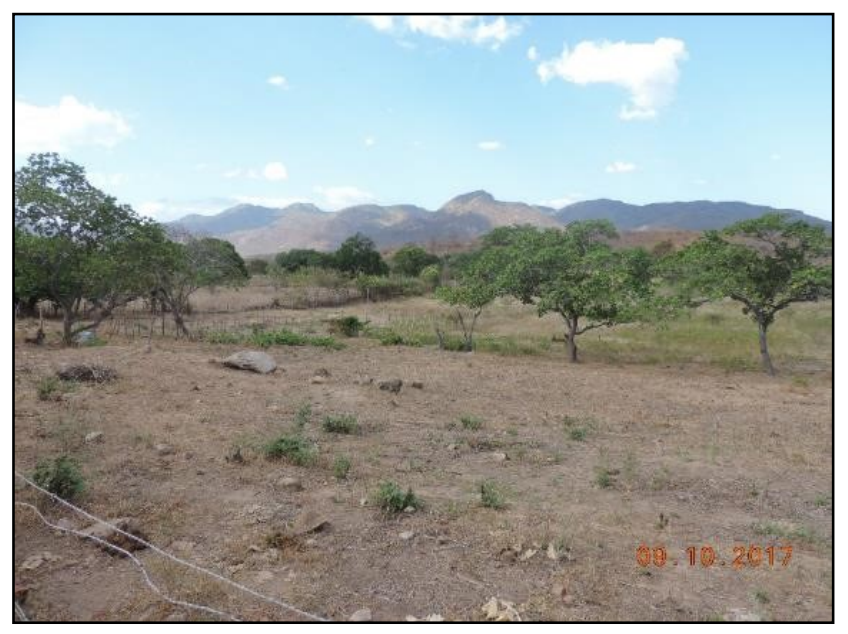

Foto: Eduardo Freires (09/10/2017)

A produção de manga apresentou uma pequena redução ao longo do período analisado. Houve uma queda de $2.213 t$ para $2.165 t$, porém, diferentemente das demais culturas, a área destinada ao plantio aumentou de 270 para 272 ha.

Os municípios de Irauçuba, Itapajé, Pentecoste, Tejuçuoca, Trairi e Umirim apresentaram redução na produção dessa cultura. Entre os municípios destaca-se Itapajé que apresentou uma queda da produção em mais de 50\%, passando de $417 \mathrm{t}$ para 208t, enquanto que a área destinada ao cultivo apresentou pequena redução, caindo de 30 para 26 ha.

Em Itapipoca, Tururu e Uruburetama foi verificada a ampliação da colheita da manga. Em Itapipoca a produção aumentou de 553t em 2007 para 653t em 2017. A área de cultivo também aumentou de 110 para 114 ha. Tururu teve sua produção de manga aumentada de 71t para 200t e a área destinada ao cultivo apresentou um crescimento de $150 \%$, passando de 10 para 25 ha.

Uruburetama chama atenção pelo fato de ter aumentado a produtividade, uma vez que conseguiu ampliar a produção em 6 toneladas numa área destinada ao cultivo que apresentou queda de 86 para 75 ha. Normalmente observa-se que 0 crescimento da produção está atrelado a ampliação da área de cultivo. 
De acordo com Souza (2006), o processo produtivo das atividades agropecuárias no semiárido cearense tem sido conquistado mais à custa de incorporações de novas terras do quem em função do aumento da produtividade.

Uruburetama foi o único a apresentar aumento da produção de todas as culturas permanentes analisadas no período. O que demonstra o el evado grau de alteração da paisagem promovido pelas atividades agrícolas no local.

Diferentemente das culturas permanentes, as principais culturas temporárias cultivadas na área de pesquisa apresentaram crescimento de produção, como pode ser observado na Tabela 4. Mandioca, feijão e sobretudo o milho apresentaram crescimento expressivo. Foi observado ainda, crescimento da área destinada ao cultivo de milho e feijão, porém houve redução das áreas de plantio de mandioca e cana-de-açúcar, como verificado na Tabela 5.

O milho foi a cultura que apresentou o crescimento mais expressivo no período analisado. Com todos os municípios apresentando crescimento, a produção do milho saltou de 7.735t em 2007 para 21.025t em 2017, uma ampliação de aproximadamente $200 \%$. A área destinada ao cultivo do milho também foi estendida, passando de 29.657 para 36.737 ha.

O crescimento da produção do milho em alguns municípios é emblemático, seja pelo grande volume alcançado, ou pela sua localização no Maciço de Uruburetama. São os casos de Itapajé, Itapipoca, Tururu, Umirim e Uruburetama, que juntos englobam a vertente úmida do maciço.

Em Itapajé mais do que dobrou a produção, passando de 673 toneladas em 2007 para 1.387t em 2107. A área destinada ao cultivo, por sua vez, foi reduzida de 2.410 para 2.150 ha. Em Itapipoca a produção cresceu quase $200 \%$, passando de 2.073t para 6.093t. Ao passo que a área destinada ao cultivo apresentou um decréscimo de 873 ha. Esse fato reflete não só a ampliação da colheita, como, também, o aumento da produtividade da cultura do milho nesses municípios. 
Tabela 4 - Produção agrícola de culturas temporárias nos municípios que compõem a vertente úmida do Maciço de Uruburetama nos anos de 2007 e 2017

\begin{tabular}{l|c|c|c|c|c|c|c|c}
\hline \multirow{2}{*}{ Município } & \multicolumn{7}{c}{ Lavoura Temporária (produção em t) } \\
\cline { 2 - 10 } & \multicolumn{2}{c}{ Milho } & \multicolumn{2}{c}{ Feijão } & \multicolumn{2}{c}{ Mandioca } & \multicolumn{2}{c}{ Cana-de-açúcar } \\
\cline { 2 - 10 } & $\mathbf{2 0 0 7}$ & $\mathbf{2 0 1 7}$ & $\mathbf{2 0 0 7}$ & $\mathbf{2 0 1 7}$ & $\mathbf{2 0 0 7}$ & $\mathbf{2 0 1 7}$ & $\mathbf{2 0 0 7}$ & $\mathbf{2 0 1 7}$ \\
\hline Irauçuba & 1.236 & 1.320 & 676 & 1.100 & 65 & 5 & -- & -- \\
Itapajé & 673 & 1.387 & 312 & 380 & 240 & 350 & 142 & 97 \\
Itapipoca & 2.073 & 6.093 & 1.631 & 2.780 & 31.298 & 25.158 & 1.936 & 259 \\
Pentecoste & 452 & 3.500 & 142 & 1.208 & 220 & 149 & 420 & -- \\
Tejuçuoca & 1.550 & 2.550 & 667 & 1.562 & 64 & 178 & --- & -- \\
Trairi & 763 & 1.713 & 815 & 1.104 & 19.309 & 17.611 & 7.039 & 5.441 \\
Tururu & 415 & 1.872 & 250 & 393 & 6.310 & 16.640 & 178 & -- \\
Umirim & 290 & 1.960 & 255 & 926 & 3.330 & 3.300 & 603 & 306 \\
Uruburetama & 283 & 630 & 142 & 240 & 90 & 170 & 52 & 107 \\
Total & $\mathbf{7 . 7 3 5}$ & $\mathbf{2 1 . 0 2 5}$ & $\mathbf{4 . 8 9 0}$ & $\mathbf{9 . 6 9 3}$ & $\mathbf{6 0 . 9 2 6}$ & $\mathbf{6 3 . 5 6 1}$ & $\mathbf{1 0 . 3 7 0}$ & $\mathbf{6 . 2 1 0}$ \\
\hline
\end{tabular}

Fonte: IBGE (2018)

Tabela 5 - Área plantada de culturas temporárias nos municípios que compõem a vertente úmida do Maciço de Uruburetama nos anos de 2007 e 2017

\begin{tabular}{|c|c|c|c|c|c|c|c|c|}
\hline \multirow{3}{*}{ Município } & \multicolumn{8}{|c|}{ Lavoura Temporária (área destinada ao cultivo em ha) } \\
\hline & \multicolumn{2}{|c|}{ Milho } & \multicolumn{2}{|c|}{ Feijão } & \multicolumn{2}{|c|}{ Mandioca } & \multicolumn{2}{|c|}{ Cana-de-açúcar } \\
\hline & 2007 & 2017 & 2007 & 2017 & 2007 & 2017 & 2007 & 2017 \\
\hline Irauçuba & 4.830 & 5.500 & 4.830 & 5.500 & 8 & 1 & --- & --- \\
\hline Itapajé & 2.410 & 2.150 & 2.414 & 2.110 & 30 & 45 & 5 & 5 \\
\hline Itapipoca & 9.900 & 9.027 & 10.128 & 9.250 & 6.900 & 3.106 & 64 & 10 \\
\hline Pentecoste & 1398 & 5.000 & 1.330 & 4.010 & 20 & 34 & 10 & --- \\
\hline Tejuçuoca & 2.640 & 5.100 & 2.270 & 5.020 & 8 & 31 & --- & --- \\
\hline Trairi & 4.740 & 3.660 & 4.812 & 3.720 & 4.042 & 3.570 & 175 & 176 \\
\hline Tururu & 1.715 & 2.600 & 1.725 & 2.605 & 1.252 & 2.082 & 5 & -- \\
\hline Umirim & 1.524 & 2.800 & 1.524 & 2.620 & 370 & 350 & 20 & 10 \\
\hline Uruburetama & 500 & 900 & 500 & 800 & 10 & 23 & 2 & 4 \\
\hline Total & 29.657 & 36.737 & 29.533 & 35.635 & 12.640 & 9.242 & 281 & 205 \\
\hline
\end{tabular}

Fonte: IBGE (2018) 
Nos Municípios de Umirim, Tururu e Uruburetama tanto a colheita quanto a área destinada ao cultivo apresentaram crescimento.

Em Umirim a produção registrada em 2007 foi 290t, com redução em 2012 para 92t, e crescimento para 1.960t em 2017. A área destinada ao cultivo saltou de 1.524 para 2800 ha no período.

Tururu e Uruburetama apresentaram crescimento expressivo. Em Tururu a produção passou de 415 t para $1.872 t$, um crescimento de mais de $450 \%$. A área destinada ao cultivo cresceu de 1.715 para 2600 ha. Em Uruburetama a colheita mais que dobrou, passando de 283t para 630t. A área de cultivo por sua vez passou de 500 para 900 ha.

Pentecoste, Tejuçuoca e Trairi, municípios do entorno do maciço, também apresentaram um significativo aumento na produção. Em pentecoste a produção saltou de 452t para 3.500t, enquanto a área de plantio cresceu de 1.398 para 5.000 ha. Em Tejuçuoca houve um crescimento de 1.550t para 2.550t, e uma ampliação da área cultivada de 2.640 para 5.100 ha. Em Trairi, por sua vez, a produção cresceu de 763t para $1.713 t$ no período. Já a área destinada ao cultivo reduziu de 4.740 para 3.660 ha.

O milho e a banana são as culturas mais difundidas no Maciço de Uruburetama. Assim como a banana, o cultivo do milho se dá sem o emprego de técnicas adequadas, sem respeitar as características do relevo e a legislação ambiental.

Sua ocorrência é maior na área de domínio da mata seca, até 600 metros de altitude, porém pode ser encontrada disseminada em toda a serra como cultura de subsistência.

Geralmente são observados no maciço o chamado cultivo morro abaixo (Figura 19), no qual o plantio é realizado no sentindo o fluxo, potencializando as enxurradas e intensificando os processos erosivos e a degradação dos solos. 
Figura 19 - Cultivo de milho morro abaixo no município de Itapipoca
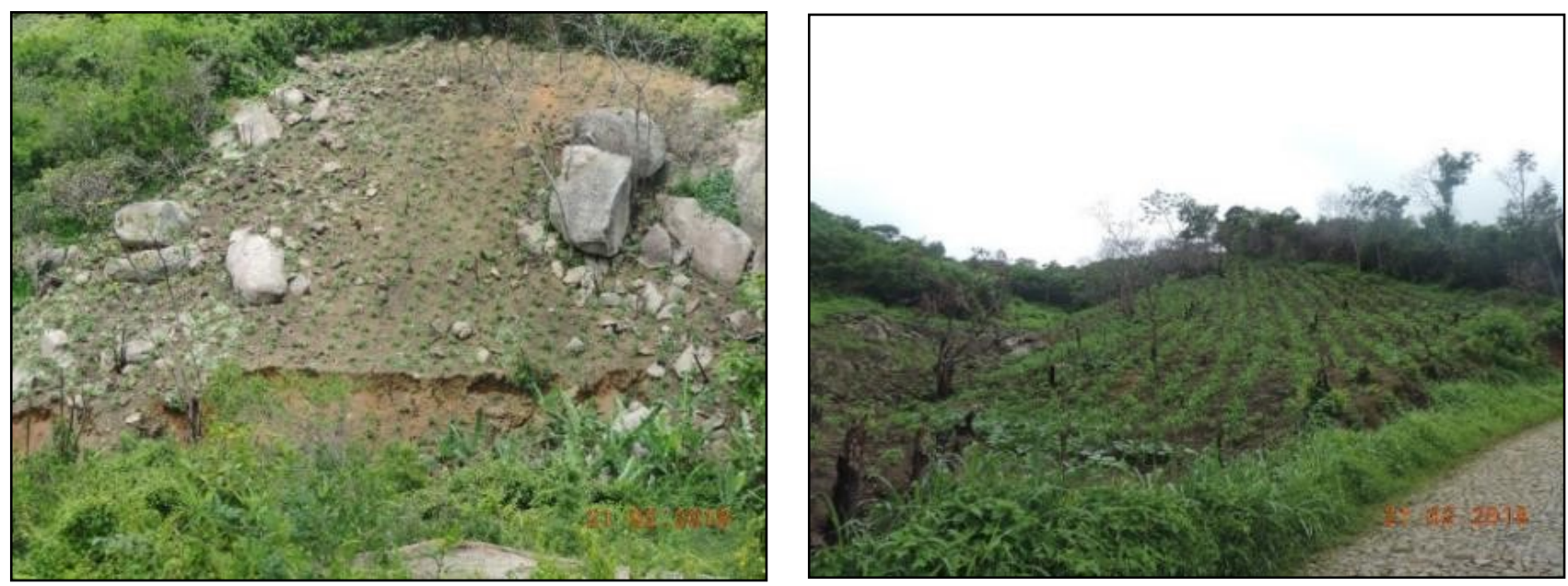

Foto: Eduardo Freires (21/02/2018)

O resultado desse tipo de cultivo é a perda gradual da produtividade do solo até a sua completa degradação a partir da formação de ravinas, que por sua vez podem evoluir para voçorocas, como pode ser observado na Figura 20. A prática da queimada que antecede a semeadura, como observado na figura 20, também reduz a fertilidade dos solos no decorrer dos anos.

Figura 20 - Cultivo morro abaixo com ocorrência de voçoroca no município de Itapajé
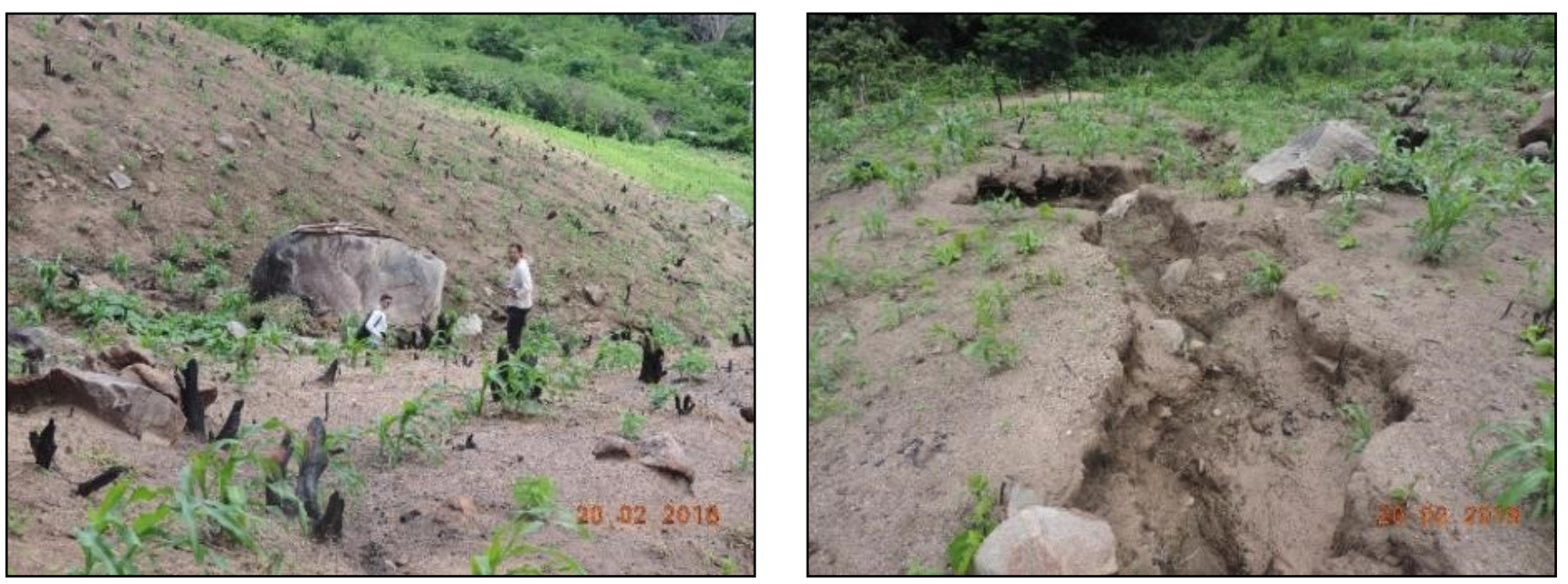

Foto: Eduardo Freires (20/02/2018)

O desconhecimento do agricultor, associado a falta de acompanhamento técnico e de fiscalização ambiental no maciço, implicou num quadro severo de alteração da paisagem que compromete a estabilidade geológica. O plantio do milho 
se dá em áreas de preservação permanente, com declividade acima de $45^{\circ}$ e nos topos de serra, como verificado na Figura 21.

Figura 21 - Cultivo de milho em área de preservação permanente no município de Itapajé

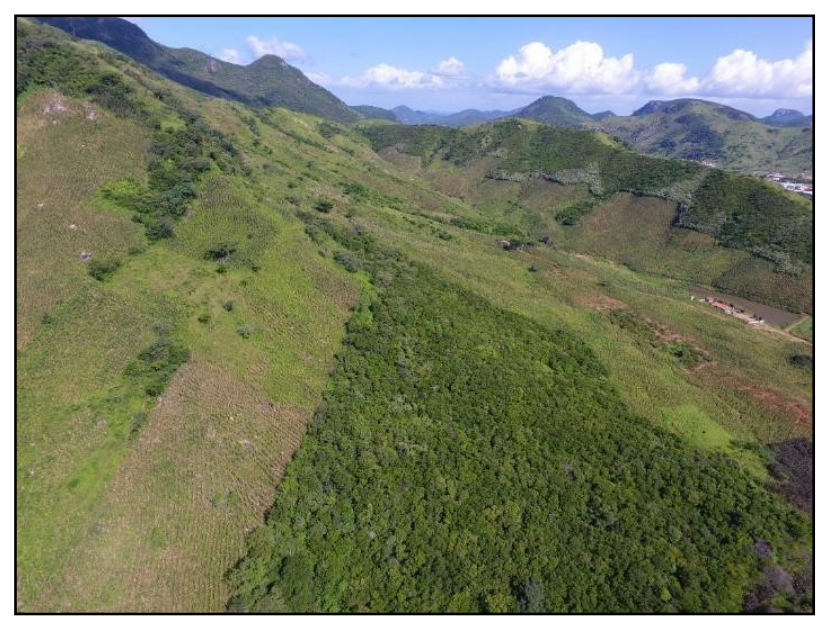

Foto: Daniel Dantas (obtida por ARP, 20/05/2017)

A cultura do feijão geralmente está associada ao cultivo do milho, consequentemente, observa-se que tanto houve uma ampliação da sua produção quanto da área destinada ao seu cultivo. Em todos os municípios da área de estudo observou-se o aumento da colheita no período analisado.

Nos Municípios de Itapipoca e Trairi houve ampliação da colheita do feijão, porém a área destinada ao cultivo apresentou redução ao longo do período. Em Itapipoca a produção passou de $1.631 \mathrm{t}$ par $2.780 \mathrm{t}$, ao passo que a área de plantio diminuiu de 10.128 para 9.250 ha. Da mesma forma em Trairi, observou-se o aumento da colheita de $815 \mathrm{t}$ para $1.104 \mathrm{t}$, enquanto que a área destinada ao cultivo reduziu de 4.812 para 3.720 ha.

Em Tejuçuoca, Umirim e Uruburetama, diferentemente, houve aumento da produção e da área de cultivo. Em Tejuçuoca a produção de feijão cresceu de $667 \mathrm{t}$ para $1.565 t$ entre 2007 e 2017. A área destinada ao plantio mais do que dobrou, passando de 2.270 para 5.020 ha. No município de Umirim a colheita cresceu substancialmente, passando de 255t para 926t. Da mesma forma foi observada a ampliação da área plantada, que aumentou de 1.524 para 2.620 ha. Em Uruburetama, por sua vez, verificou-se que a produção de feijão cresceu de 142t em 
2007 para 240t em 2017, enquanto sua área de plantio foi ampliada de 500 para 800 ha.

A colheita da mandioca seguiu a tendência do milho e do feijão e apresentou crescimento entre os anos de 2007 e 2017. A produção de mandioca passou de 60.926t em 2007 para 63.561t em 2017. Todavia, a área destinada ao cultivo dessa cultura foi reduzida de 12.640 para 9.242 ha, o que representa um aumento de produtividade.

O crescimento observado na produção da mandioca na área de estudo foi alavancado pelos municípios de Itapajé, Uruburetama, Tururu e Tejuçuoca, tendo os demais apresentado diminuição.

Em Itapajé, a produção passou de 240t em 2007 para 350t em 2017. A área destinada ao cultivo em 2017 acompanhou essa tendência e saltou de 30 para 45 ha. Em Uruburetama a colheita cresceu de 90t em 2007 para 170t em 2017. Seguindo essa tendência a área de plantio no período aumentou de 10 para 23 ha.

Em Tururu a colheita subiu de 6.310t em 2007 para 16.640 t em 2017, enquanto que a área de plantio passou de 1.252 para 2.082 ha. Em Uruburetama a produção aumentou de 64 t para 178 t e a área e cultivo cresceu de 8 para 31 ha.

Diferente das demais culturas a produção da cana-de-açúcar apresentou redução no período. Pentecoste e Tururu não apresentaram registro de produção para o ano de 2017, contribuindo para essa queda. A colheita de cana-de-açúcar reduziu de 10.370t, em 2007, para 6.210t em 2017. A área destinada ao cultivo também diminuiu, passando de 281 para 205 ha.

Os municípios de Trairi e, principalmente, Itapipoca puxaram a queda dos indicadores. Em Itapipoca a produção de cana-de-açúcar apresentou um declínio em mais de 7 vezes no período. Entre os anos de 2007 e 2017 foi observada uma queda da colheita de 1.936t para 259t, enquanto que a área de cultivo diminuiu de 64 para 10 ha. Em Trairi observou-se também queda da produção, tendo a colheita passado de 7.039t em 2007 para 5.441t em 2017. Porém a área destinada ao cultivo apresentou pequena oscilação. 
Uruburetama foi o único município a apresentar crescimento da produção da cana-de-açúcar. A colheita registrada em 2007 foi de 52t, enquanto em 2017 atingiu 107t. A variação da área destinada ao cultivo foi compatível a dinâmica de produção.

É importante ressaltar que, diferentemente das demais culturas, não houve registro de produção de cana-de-açúcar nos municipais de Irauçuba e Tejuçuoca ao longo do período analisado.

Juntamente com a agricultura, a pecuária e o extrativismo vegetal contribuem também para o quadro de degradação local. Muitos sertanejos de baixa renda ainda tem o carvão vegetal como única fonte de combustível. Para isso suprimem espécies da caatinga para queima e produção do carvão. Ainda hoje essa vegetação também é a principal fonte de combustível na produção de telhas e tijolos em olarias e/ou cerâmicas na área. A pecuária extensiva praticada nos sertões, por sua vez, contribui tanto na supressão da vegetação como também na degradação dos solos, uma vez que o pisoteio do gado promove sua compactação, que diminui a permeabilidade e favorece a erosão laminar.

As alterações produzidas pelas atividades humanas são responsáveis pelo elevado grau de degradação no Maciço de Uruburetama. A agricultura se configura como o principal agente transformador da paisagem e gradativamente vem comprometendo a conservação ambiental. A marca do antropismo se manifesta através do desmatamento indiscriminado e do manejo inadequado dos solos e dos recursos hídricos, que por sua vez aceleram os processos erosivos, com consequente adelgaçamento dos solos, e intensificam o assoreamento de rios e açudes.

A agricultura de subsistência está disseminada por toda área de estudo. A sistemática da lavoura de subsistência consiste na retirada sumária da vegetação primária, seguida pela queima e preparo do solo para plantio. Após alguns anos é deixado em pousio, para recuperação e posterior retomada da prática agrícola. Procedimento que irá ser repetido até o esgotamento do solo, quando então será 
abandonado e novas áreas serão buscadas para cultivo, o que configura a agricultura itinerante, comum na área de domínio do clima semiárido.

Como consequência do manejo inadequado dos solos podem ocorrer diversos impactos, como: diminuição da produção e da produtividade agropecuária, perda do dinamismo das atividades ligadas ao setor primário da economia, desemprego crescente, redução da qualidade de vida, concentração de renda e ampliação do processo migratório.

Embora seja observado de forma disseminada práticas agrícolas predatórias por todo o maciço, é possível verificar no Quadro 3 que os municípios de Irauçuba, Itapajé, Itapipoca, Pentecoste e Tejuçuoca dispõem de leis que tratam sobre o parcelamento e zoneamento ou uso e ocupação do solo rural. Uma verdadeira contradição, já que não são observadas a implementação de instrumentos legais e/ou técnicos para garantir a preservação ou sustentabilidade ambiental no maciço.

Quadro 3 - Ocorrência de legislação municipal sobre o solo rural

\begin{tabular}{|l|cc|}
\hline \multicolumn{1}{|c|}{ Municípios } & \multicolumn{2}{|c|}{ Legislação municipal sobre solo rural } \\
\cline { 2 - 3 } & Parcelamento & Zoneamento ou Uso e Ocupação \\
\hline Irauçuba & SIM & SIM \\
Itapajé & SIM & SIM \\
Itapipoca & SIM & SIM \\
Pentecoste & SIM & SIM \\
Tejuçuoca & SIM & SIM \\
Trairi & NÃO & NÃO \\
Tururu & NÃO & NÃO \\
Umirim & NÃO \\
Uruburetama & NÃO & NÃO \\
\hline
\end{tabular}

Fonte: IBGE (2018)

Como pode ser observado no Quadro 4, em vários municípios ocorreram processos erosivos acelerados entre 2013 e 2017, inclusive Irauçuba e Pentecoste, que dispõem de legislação para disciplinar o uso e ocupação da terra. Tal fato reflete a baixa capacidade de gerenciamento dos órgãos competentes. 
Quadro 4 - Ocorrência de processos erosivos acelerados nos municípios da área de estudo

\begin{tabular}{|l|c|}
\hline \multicolumn{2}{|c|}{ Municípios atingidos por processos erosivos acelerados entre $\mathbf{2 0 1 3}$ e $\mathbf{2 0 1 7}$} \\
\hline Irauçuba & $\mathrm{SIM}$ \\
Itapajé & $\mathrm{NÃO}$ \\
Itapipoca & $\mathrm{NÃO}$ \\
Pentecoste & $\mathrm{SIM}$ \\
Tejuçuoca & $\mathrm{NÃO}$ \\
Trairi & $\mathrm{SIM}$ \\
Tururu & $\mathrm{NÃO}$ \\
Umirim & NÃO SABE \\
Uruburetama & $\mathrm{SIM}$ \\
\hline
\end{tabular}

Fonte: IBGE (2017)

É premente que seja implementada de forma eficaz a fiscalização de todas as intervenções no maciço, bem como promover a recuperação das áreas degradadas no intuito de garantir a sustentabilidade agrícola, a manutenção dos ecossistemas, e a estabilidade das encostas no intuito de evitar ou reduzir os problemas ambientais, econômicos e sociais derivados dos processos erosivos e dos movimentos de massa. Para isso é necessário o desenvolvimento de estudos técnicos (zoneamento, Plano Diretor, cartas geotécnicas de aptidão a urbanização, mapeamento e cadastro de áreas de risco) para subsidiar os órgãos competentes na Gestão e planejamento ambiental do maciço.

\section{CONCLUSÕES}

As diversas intervenções antrópicas realizadas ao longo dos anos no Maciço de Uruburetama têm gerado vários problemas de ordem ambiental, econômica e social que por sua vez compromete a sustentabilidade local e a manutenção das próximas gerações.

A expansão urbana e a maior demanda de recursos a partir do crescimento populacional verificado nos municípios que compõem a área de estudo, aliada a falta orientação técnica e fiscalização das atividades praticadas, vem promovendo um quadro de degradação da vertente úmida do Maciço de Uruburetama que pode se tornar irreversível. 
A ampliação da malha urbana e das áreas de cultivo ocorrem indiscriminadamente em áreas de preservação permanente, como nas encostas com declividade superior a $45^{\circ}$ ou em topos de morros e serras com alturas superiores a 100 metros e com inclinação média superior a $25^{\circ}$, desrespeitando as determinações da Lei Federal n 12.651/2012 (Código Florestal Brasileiro) que visa, entre outros objetivos, preservar as paisagens, a estabilidade geológica e proteger o solo.

As atividades agrícolas são efetuadas a partir da supressão da cobertura vegetal primária, que por si só já expõe os solos aos agentes erosivos, e em sua grande maioria são realizadas no chamado cultivo morro abaixo, em que as culturas são cultivadas no sentido do fluxo superficial intensificando os processos erosivos e os movimentos de massa. O uso inadequado de irrigação também vem contribuindo para potencializar esses fenômenos. Como consequência observa-se a perda gradativa da produtividade agrícola. É premente que órgãos gestores locais desenvolvam políticas de acompanhamento técnico junto aos produtores rurais no intuito de orientar a prática agrícola no que diz respeito a sistemática de plantio em encostas, ao tipo de irrigação adotado e visando a compatibilização de culturas às características ambientais do maciço, respeitando os limites impostos pelo meio e a legislação.

De 2007 a 2017 foi verificado que as principais culturas permanentes apresentaram um decréscimo na produção, todavia as áreas destinadas ao cultivo dessas culturas tiveram uma pequena redução. Por outro lado, foi observado que as principais culturas temporárias apresentaram crescimento na produção e na área destinada ao cultivo.

Dessas culturas se destacam o cultivo da banana (cultura permanente) e do milho (cultura temporária) pelo grau de alteração imposto a paisagem, e todos os problemas ambientais derivados de suas práticas. É possível observar setores da vertente úmida completamente cultivados com bananeiras, assim como áreas de domínio da mata seca completamente descaracterizadas pelo plantio do milho.

O município de Uruburetama, único localizado completamente na vertente úmida, chama atenção pelo fato de apresentar a maior densidade populacional da área de estudo, com 203,61 hab./km², e pela constatação do crescimento na produção agrícola de todas 
as culturas no período analisado (2007 - 2017), resultado alcançado, geralmente, à custa da ampliação da área de cultivo, que, por sua vez, reflete na alteração da paisagem dentro dos seus limites administrativos.

O corte de encostas para abertura de estradas, realizado pelo poder público para integrar as localidades, é um dos principais condicionantes para a ocorrência de movimento de massa. Sem a adoção de técnicas de estabilização dos taludes, as vertentes são expostas aos processos erosivos. Em áreas de cultivos cortadas por estradas é possível encontrar com frequência movimento de massa. A ocorrência de estradas em áreas de cultivo da banana é uma associação propícia a deflagração desses fenômenos.

Também é possível observar o corte de encostas para ampliação de áreas edificáveis, sem qualquer medida de estabilização dos taludes, que colocam em risco os moradores locais. Da mesma forma, a diminuição dos espaços passíveis de ocupação e ampliação do valor da terra, tem levado muitas pessoas a ocuparem áreas com risco geológico, que apresentam declividade considerável ou que estão em rota de colisão de blocos de rocha ou matacão.

Embora todos os municípios da área de pesquisa disponham de órgão gestor ambiental, e que alguns possuam leis que disciplinem o uso e ocupação da terra, percebesse que suas atuações ocorrem de forma deficitária, seja por falta de recursos financeiros, técnicos e humanos. A maioria desses órgãos atuam integrados a outros setores da administração pública, como agricultura, pecuária, recursos hídricos, cultura e turismo. A resolução de determinados problemas de ordem ambiental muitas vezes passa por conflitos de interesse que podem inibir a tomada de decisão dos órgãos gestores.

Sugere-se que todos os municípios que abrangem a área de pesquisa desenvolvam estudos técnicos (zoneamento, Plano Diretor, cartas geotécnicas de aptidão a urbanização, mapeamento e cadastro de áreas de risco, entre outros) e leis que orientem e disciplinem o uso e ocupação da terra.

Compreende-se a necessidade de implementação de uma Área de Proteção Ambiental (APA) na serra por parte da Secretaria do Meio Ambiente do Estado do Ceará (SEMA), e consequentemente uma atuação efetiva da Superintendência Estadual de Meio 
Ambiente (SEMACE) na fiscalização da expansão urbana e das atividades agrícolas, bem como, na capacitação de recursos humanos junto aos órgãos locais para atuarem em seus municípios. É necessário que sejam efetuados métodos e técnicas de proteção e estabilização dos taludes de corte das estradas construídas pelo poder público, no intuito de diminuir os riscos, a perda de solos e evitar que as comunidades fiquem isoladas em decorrência dos movimentos de massa. Da mesma forma, é de suma importância a recuperação de áreas degradadas visando garantir o desenvolvimento da prática agrícola e a estabilidade das encostas.

\section{REFERÊNCIAS}

AB'SABER NA. O domínio morfoclimático semiárido das caatingas brasileiras. Geomorfologia. 1974; 43: 1-39.

AYOADE JO. Introdução à climatologia para os trópicos. 18. ed. Rio de Janeiro: Bertrand Brasil; 2015. $350 \mathrm{p}$.

BARBOSA H. Ceará possui 175 cidades incluídas no Semiárido. Diário do Nordeste [Internet]. 2017 Nov 28 [cited 2019 aug 15]. Região. Available from:

https://diariodonordeste.verdesmares.com.br/editorias/regiao/ceara-possui-175-cidadesincluidas-no-semiarido-1.1857199.

BRANDÃO RL. Sistema de Informações para a Gestão e administração Territorial da Região Metropolitana de Fortaleza - Projeto SINFOR. Diagnóstico Geoambiental e os principais problemas de ocupação do meio físico da Região Metropolitana de Fortaleza. v.1. Fortaleza: CPRM, 1995. 105 p.

BRANDÃO RL. Zoneamento Geoambiental da região de Irauçuba/CE. Texto explicativo/ Carta Geoambiental. Fortaleza: CPRM, 2003. 67 p.

BRANDÃO RL, FREITAS LCB. Geodiversidade do estado do Ceará. Fortaleza: CPRM, 2014. 214 p.

CAVALCANTE JC, VASCONCELOS AM, MEDEIROS MF, PAIVA IG. Mapa Geológico do Estado do Ceará. 1. edição. Fortaleza: CPRM, 2003. Escala 1:500.000.

CHRISTOFOLETTI A. Geomorfologia Fluvial. São Paulo: Edgard Blücher, 1981. 313 p.

DEPARTAMENTO NACIONAL DE OBRAS CONTRA A SECA [internet]. Brasília: Ministério da Integração Nacional (BR) [cited 2018 jan 29]. Açude Caxitoré: descrição geral. Available from: http://www.dnocs.gov.br/ dnocs/doc/canais/barragens/Barragem\%20do\%20Ceara/mundau.htm. 
DEPARTAMENTO NACIONAL DE OBRAS CONTRA A SECA [internet]. Brasília: Ministério da Integração Nacional (BR) [cited 2018 jan 29]. Açude Mundaú: descrição geral. Available from: http://www.dnocs.gov.br/ dnocs/doc/canais/barragens/barragem\%20do\%20ceara/caxitore.htm.

EMPRESA BRASILEIRA DE PESQUISA AGROPECUÁRIA. Sistema brasileiro de classificação de solos. Rio de Janeiro (Brasil): EMBRAPA-SPI, 2009. 367p.

FERNANDES A. Conexões florísticas do Brasil. Fortaleza: Banco do Nordeste, 2003. 134 p.

FERNANDES A. Fitogeografia Brasileira: províncias Florísticas. 3. ed. Fortaleza: Realce Editora e Indústria Gráfica, 2006. 202 p.

FREIRES EV, SILVA NETO CA, CUNHA DSR, DUARTE CR, VERÍSSIMO CUV, GOMES, DDM. Comparação de Imagens OLI/Landsat-8 e MSI/Sentinel-2 no Mapeamento de Cobertura e Uso da Terra no Maciço de Uruburetama, Ceará. Anuário do Instituto de Geociências. 2019; 42(4): 427-442.

GUERRA AT, GUERRA AJT. Novo dicionário geológico-geomorfológico. Rio de Janeiro: Bertrand Brasil, 1997. 652p.

INSTITUTO BRASILEIRO DE GEOGRAFIA E ESTATÍSTICA. Manual técnico de pedologia. 2. ed. Rio de Janeiro (Brasil): IBGE, 2007. 315 p.

INSTITUTO BRASILEIRO DE GEOGRAFIA E ESTATÍSTICA [Internet]. Brasília: Ministério do Planejamento, Orçamento e Gestão (BR) [citado em 16 mai. 2018]. Mapa de climas zonais em escala de 1:5.000.000. Rio de Janeiro: IBGE, 2002. Available from:

https://atlasescolar.ibge.gov.br/images/atlas/mapas_brasil/brasil_clima.pdf.

INSTITUTO BRASILEIRO DE GEOGRAFIA E ESTATÍSTICA [Internet]. Brasília: Ministério do Planejamento, Orçamento e Gestão (BR) [cited 2018 feb 15]. Mapa temático de Pedologia em escala de 1:250.000. Rio de Janeiro: IBGE, 2017. Available from:

ftp://geoftp.ibge.gov.br/informacoes_ambientais/pedologia/vetores/escala_250_mil/recorte_milio nesimo/.

INSTITUTO BRASILEIRO DE GEOGRAFIA E ESTATÍSTICA [Internet]. Brasília: Ministério do Planejamento, Orçamento e Gestão (BR) [cited 2018 oct 28]. Portal das cidades: panorama/ população. Available from: https://cidades.ibge.gov.br.

INSTITUTO BRASILEIRO DE GEOGRAFIA E ESTATÍSTICA [Internet]. Brasília: Ministério do Planejamento, Orçamento e Gestão (BR) [cited 2018 oct 30]. Portal das cidades: produção agrícola. Available from: https://cidades.ibge.gov.br.

INSTITUTO NACIONAL DE PESQUISAS ESPACIAIS [Internet]. Brasília: Ministério da Ciência, Tecnologia, Inovações e Comunicações (BR) [cited 2018 jul 01]. SPRING 5.5.3. Available from: http://www.dpi.inpe.br/SPRING/portugues/download.php. 
INSTITUTO DE PESQUISA E ESTRATÉGIA ECONÔMICA DO CEARÁ. Fortaleza: Secretária do Planejamento e Gestão do Estado do Ceará (CE) [cited 2018 jul 02]. Mapa das unidades fitoecológicas do Estado do Ceará. Available from:

http://www2.ipece.ce.gov.br/atlas/capitulo1/12/pdf/Unidades_Fitoecologicas.pdf.

MENDONÇA F, DANNI-OLIVEIRA IM. Climatologia: noções básicas e climas do Brasil. São Paulo: Oficina de Textos, 2007. 206 p.

MINISTÉRIO DO MEIO AMBIENTE. Lei $\mathbf{n}^{\circ}$ 12.651, de 25 de maio de 2012 (Novo Código Florestal) Dispõe sobre a proteção da vegetação nativa; altera as Leis $n^{\circ}$ s 6.938 , de 31 de agosto de 1981, 9.393, de 19 de dezembro de 1996, e 11.428, de 22 de dezembro de 2006; revoga as Leis n's 4.771, de 15 de setembro de 1965, e 7.754, de 14 de abril de 1989, e a Medida Provisória n 2.166-67, de 24 de agosto de 2001; e dá outras providências. Brasília (Brasil): Ministério do Meio Ambiente; 2012.

MORAIS JO. Compartimentação territorial evolutiva da zona costeira. In: LIMA LC, MORAIS JO, SOUZA, MJN, editors. Compartimentação Territorial e Gestão Regional do Ceará. Fortaleza: FUNECE; 2000. p. 105-184.

OLIVEIRA VPV. Prospección, caracterização y cartografia edafopaisagistica em uma région montañosa del semiárido brasileiro: la Sierra de Uruburetama/Sertão Nordestino-CearáBrasil [thesis]. Almeria: Faculdade de Ciencias experimentales/Universidad de Almeria; 2002. 585 p.

PALMIERI F, LARACH JOI. Pedologia e geomorfologia. In: GUERRA AJT, CUNHA SB, editores. Geomorfologia e meio ambiente. 5. ed. Rio de Janeiro: Bertrand Brasil; 2004. p. 59 - 122.

RIZZINI CT. Tratado de fitogeografia do Brasil. São Paulo: Âmbito Cultural Edições Ltda, 1997. 746 p.

SCHOBBEnHAUS C, NEVES BBB. A Geologia do Brasil no Contexto da Plataforma SulAmericana. In: BIZZI LA, SCHOBBENHAUS C, VIDOTTI RM, GONÇALVES JH. Geologia, tectônica e recursos minerais do Brasil. Brasília: CPRM - Serviço Geológico do Brasil; 2003. p. 5 - 86.

SECRETARIA DE RECURSOS HÍDRICOS DO CEARÁ [internet]. Fortaleza: Companhia de Gestão de Recursos hídricos (CE) [cited 2018 jan 29]. Atlas dos recursos hídricos do Ceará. Available from: http://atlas.srh.ce.gov.br/infraestrutura/acudes/detalhaCaracteristicasTecnicas.php?cd_acude=26 $7 \&$.

SILVA MVC. Análise Geoambiental: subsídios ao planejamento agrícola da Serra de Uruburetama - Ce [dissertation]. Fortaleza: Mestrado Acadêmico de Geografia/ Universidade Estadual do Ceará 2007. $191 \mathrm{p}$.

SOUZA MJN. Bases naturais e esboço do zoneamento geoambiental do estado do Ceará. In: LIMA LC, MORAIS JO, SOUZA MJN, editors. Compartimentação Territorial e Gestão Regional do Ceará. Fortaleza: FUNECE; 2000. p.5-104. 
SOUZA MJN. Contexto Geoambiental do semiárido do Ceará: problemas e perspectivas. In: SOBRINHO JF, FALCÃO CLC, editors. Semi-Árido: diversidades, fragilidades e potencialidades. Sobral: Sobral Gráfica; 2006. p.14-33.

SOUZA MJN, NETO JM, SANTOS JO, GONDIM MS. Diagnóstico Geoambiental do Município de Fortaleza: subsídio ao macrozoneamento ambiental e à revisão do Plano Diretor ParticipativoPDPFor. Fortaleza: Prefeitura Municipal de Fortaleza, 2009. 172 p.

SOUZA MJN, OLIVEIRA VPV. Os enclaves úmidos e sub-úmidos do semi-árido do Nordeste brasileiro. Mercator - Revista de Geografia da UFC. 2006;09: 85-102.

SUGUIO K, BIGARELA JJ. Ambiente fluvial. Curitiba: Editora Universidade Federal do Paraná , 1979. $189 \mathrm{p}$.

UNITED STATES GEOLOGICAL SURVEY. Departamento do Interior dos E.U.A [cited 2018 may 05]. Imagem MSI/Sentinel-2 de 26 de setembro de 2017. Available from: http://earthexplorer.usgs.gov/.

\section{CONTRIBUIÇÕES DE AUTORIA}

\section{1 - Eduardo Viana Freires}

Mestre e Doutor em Geologia pela Universidade Federal do Ceará. Também é PósDoutorando em Geologia pela Universidade Federal do Ceará Atualmente é professor de Geografia da Rede Municipal de Maracanaú, da Rede Estadual do Ceará, e Geógrafo, com Registro Profissional № 54408 no Conselho Regional de Engenharia, Arquitetura e Agronomia (CREA).

https://orcid.org/0000-0001-7010-5260 - eduardovgeo@gmail.com

Contribuição: Levantamento, processamento, análise de dados e escrita.

\section{2 - Cláudio Ângelo da Silva Neto}

Possui Bacharelado em Geologia. Atualmente, é Mestrando em Geologia pela Universidade Federal do Ceará e Integrante do grupo de pesquisa Geoprocessamento e Modelagem de Dados Geoambientais e do Laboratório de Geoprocessamento do Ceará (GEOCE).

https://orcid.org/0000-0002-6749-9438 - claudioasn@gmail.com

Contribuição: Levantamento, processamento, análise de dados e escrita.

\section{3 - Cynthia Romariz Duarte}

Mestra e Doutora em Geologia Regional pela Universidade Estadual Paulista Júlio de Mesquita Filho. Atualmente é Professora do curso de graduação em Geologia e do Programa de Pós-graduação em Geologia na Universidade Federal do Ceará. Além disso, é Coordenadora do Programa de Pós-graduação em Geologia da Universidade Federal do Ceará. Responsável pelo subprojeto LAGEM - Laboratório de Geomodelagem, MCTI/FINEP/CTINFRA e coordenadora do Grupo de Pesquisa Geoprocessamento e 
Modelagem de Dados Geoambientais, cadastrado no Diretório de Grupos de Pesquisa no Brasil.

https://orcid.org/0000-0002-0255-4045 - cynthia.duarte@ufc.br

Contribuição: Levantamento, processamento, análise de dados e escrita.

\section{4 - César Ulisses Vieira Veríssimo}

Possui graduação em Geologia, mestrado em Geologia, doutorado em Geologia Regional pela Universidade Estadual Paulista Júlio de Mesquita Filho e pós-doutorado no Instituto de Geociências. Atualmente é professor Titular da Universidade Federal do Ceará. https://orcid.org/0000-0002-5055-9617 - verissimo@ufc.br Contribuição: Levantamento, análise de dados e escrita.

\section{5 - Daniel Dantas Moreira Gomes}

Possui Graduação em Geografia, Mestrado e Doutorado em Geologia pela Universidade Federal do Ceará, Pós-Doutorado em Geografia Física (Cartografia), Pós-Doutorando em Geografia (Biogeografia). Atualmente é Professor de Geociências da Universidade de Pernambuco, Docente do Programa de Pós-Graduação em Saúde e Desenvolvimento Socioambiental e, Coordenador do Laboratório de Geoprocessamento e Modelagem Ambiental - LaGMA.

https://orcid.org/0000-0001-6868-040X - daniel.gomes@upe.br

Contribuição: Levantamento, análise de dados e escrita.

\section{6 - Allison de Oliveira Maia}

Possui graduação e mestrado em Geologia pela Universidade Federal do Ceará. https://orcid.org/0000-0002-5976-9856 - allisonoliveira@yahoo.com.br Contribuição: Levantamento, análise de dados e escrita.

\section{Como citar este artigo}

FREIRES, E. V.; SILVA NETO, C. A.; DUARTE, C. R.; VERISSIMO, C. U. V.; GOMES, D. D. M.; MAIA, A. O.; Diagnóstico da degradação ambiental na Vertente Úmida do Maciço de Uruburetama/CE e seu entorno. Ciência e Natura, Santa Maria, v. 43, e18, p. 1-55, 2021. Disponível em: https://doi.org/10.5902/2179460X40521. Acesso em: dia, mês (abreviado), ano. 